Keywords: DWPF, SB6, $\mathrm{Hg}$, ammonia, hydrogen

Retention: Permanent

\title{
Sludge Batch 6 Supplemental SRAT Runs: Effects of Yield Stress and Cycle Time Increase
}

\author{
A. I. Fernandez
}

August 2010

Savannah River National Laboratory Savannah River Nuclear Solutions Aiken, SC 29808

Prepared for the U.S. Department of Energy under contract number DE-AC09-08SR22470.

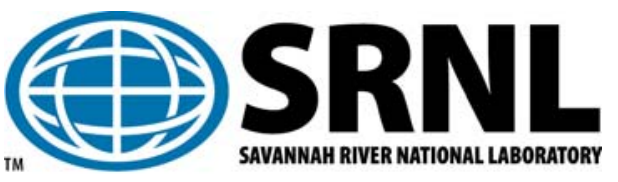


SRNL-STI-2010-00307

Revision 0

\section{DISCLAIMER}

This work was prepared under an agreement with and funded by the U.S. Government. Neither the U.S. Government or its employees, nor any of its contractors, subcontractors or their employees, makes any express or implied:

1. warranty or assumes any legal liability for the accuracy, completeness, or for the use or results of such use of any information, product, or process disclosed; or

2. representation that such use or results of such use would not infringe privately owned rights; or

3. endorsement or recommendation of any specifically identified commercial product, process, or service.

Any views and opinions of authors expressed in this work do not necessarily state or reflect those of the United States Government, or its contractors, or subcontractors.

\section{Printed in the United States of America \\ Prepared for \\ U.S. Department of Energy}




\section{REVIEWS AND APPROVALS}

AUTHORS:

\begin{tabular}{ll}
\hline A.I. Fernandez, Process Technology Programs & Date
\end{tabular}

TECHNICAL REVIEW:

M.E. Stone, Process Technology Programs

Date

D.C. Koopman, Process Technology Programs

Date

APPROVAL:

C.C. Herman, Manager

Date

Process Technology Programs

S.L. Marra, Manager

Date

Environmental \& Chemical Process Technology Research Programs

J.E. Occhipinti, Manager

Date

Waste Solidification Engineering 


\section{EXECUTIVE SUMMARY}

The Defense Waste Processing Facility (DWPF) has transitioned from Sludge Batch 5 (SB5) processing to Sludge Batch 6 (SB6) processing. Phase III-Tank 40 Chemical Process Cell (CPC) flowsheet simulations have been completed to determine the initial processing conditions for the DWPF transition. The impact of higher yield stress (SB-25) and cycle time extension (SB6-26) on the physical and chemical effects of SB6 processing during the SRAT (Sludge Receipt and Adjustment Tank) cycle were evaluated.

No significant impacts on the SRAT chemistry were noted during the higher yield stress run. In particular, no impact on mercury stripping was noted, indicating that settling of elemental mercury was not the primary factor in the low mercury recovery noted in the flowsheet testing. The SRAT product from this run retained the higher yield stress of the starting sludge. The run indicated that ultrasonication is an effective tool to increase the yield stress of simulants to targeted values and the chemistry of downstream processing is not impacted.

Significant differences were noted in the cycle time extension test compared to the Phase III flowsheet baseline runs. Large decreases in the ammonia and hydrogen generation rates were noted along with reduced mercury stripping efficiency. The latter effect is similar to that of operating under a high acid stoichiometry. It is conceivable that, under the distinctly different conditions of high formic acid concentration (high acid run) or slow formic acid addition (extended run), that mercury could form amalgams with noble metals, possibly rendering both inert. Thus, the removal of free mercury and noble metals could decrease the rate of catalytic formic acid reactions which would decrease generation of ammonium and hydrogen. The potential underlying reasons for the behavior noted during this run would require additional testing. 


\section{TABLE OF CONTENTS}

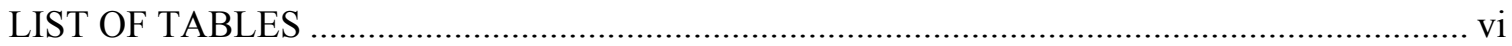

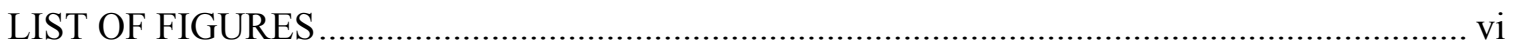

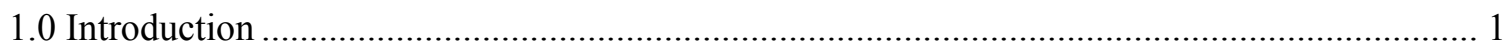

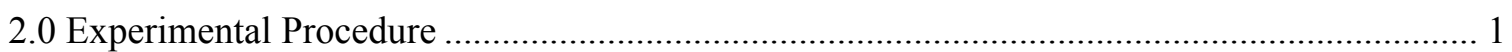

2.1 Process and Sample Analytical Methods ........................................................................... 1

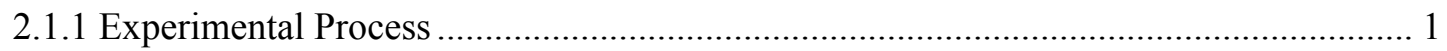

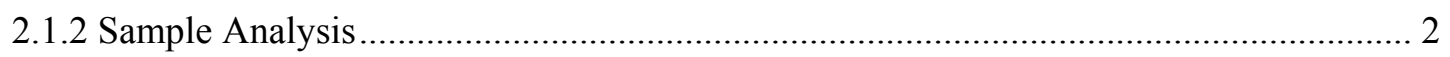

2.2 Chemical Process Cell (CPC) Simulation Detail ................................................................ 2

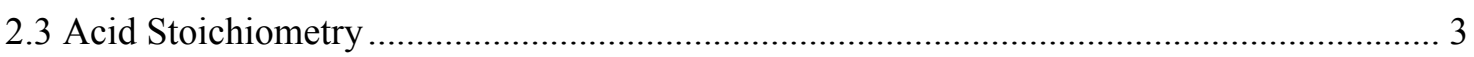

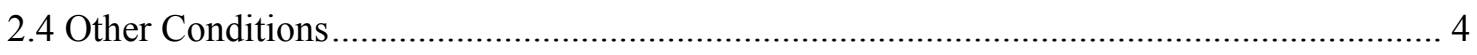

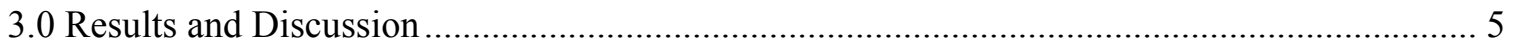

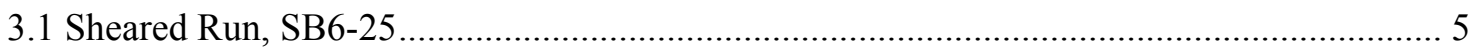

3.1.1 Rheological and particle size results, SB6-25 ...................................................... 5

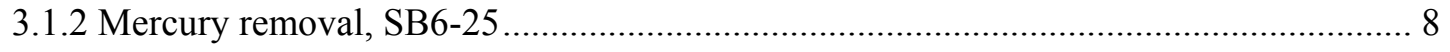

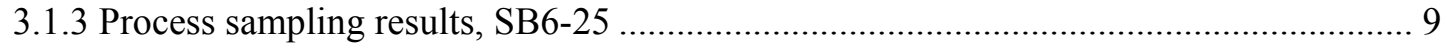

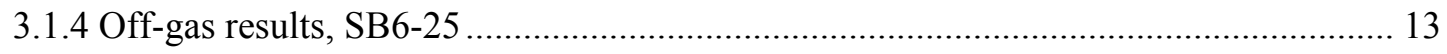

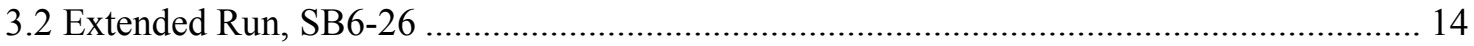

3.2.1 Rheological and particle size results, SB6-26 …....................................................... 15

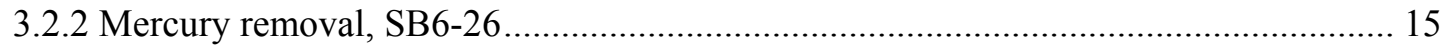

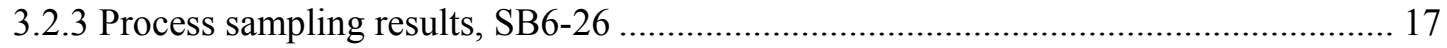

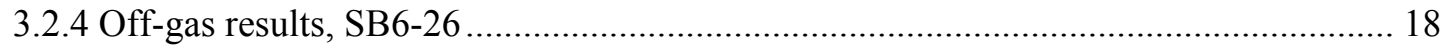

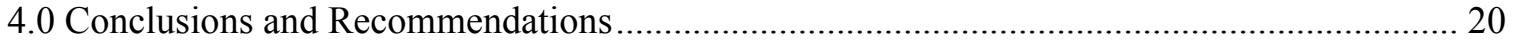

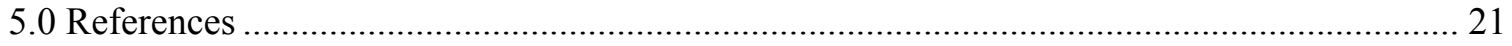

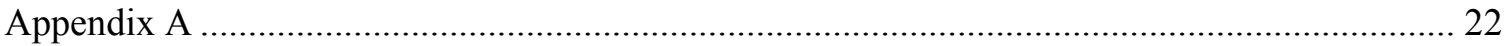




\section{LIST OF TABLES}



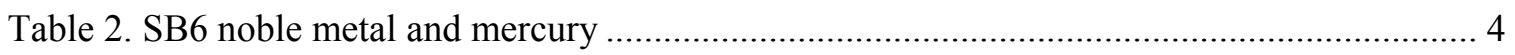

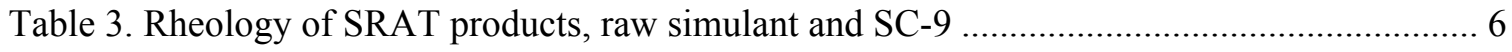

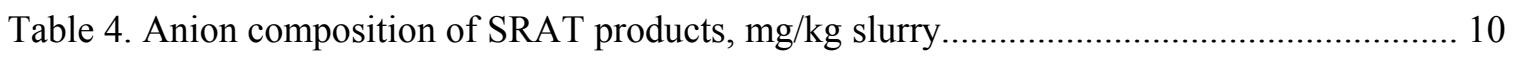

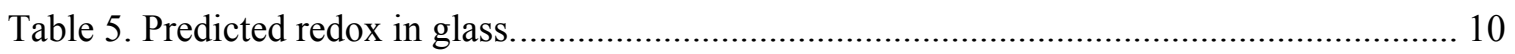

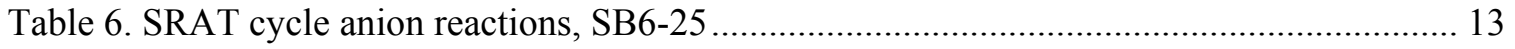

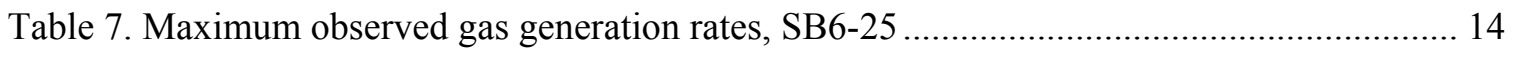

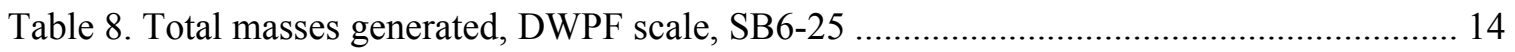

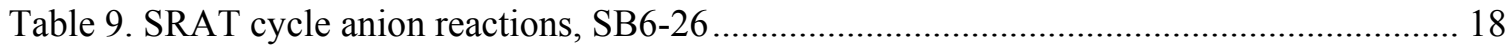

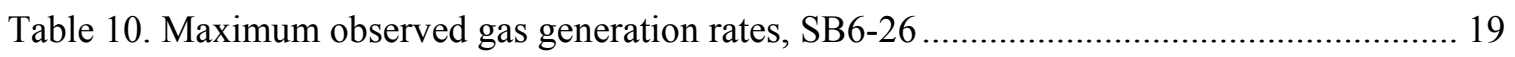

Table 11. Total masses generated, DWPF scale, SB6-26 ......................................................... 19

Table 12. Elemental compositions of simulant and SRAT product slurries, calcined $\mathrm{wt} \%$.......... 26

Table 13. Elemental compositions of simulant and SRAT product supernates, $\mathrm{mg} / \mathrm{L}$.................. 26

Table 14. Anion composition of SRAT slurry one-half hour from end of reflux, $\mathrm{mg} / \mathrm{kg}$ slurry ... 27

Table 15. Anion composition of SRAT slurry at end of acid addition, $\mathrm{mg} / \mathrm{kg}$ slurry .................. 27

Table 16. Elemental compositions of simulant and SRAT supernate at end of acid addition, $\mathrm{mg} / \mathrm{L}$

Table 17. Anion composition of MWWT composite dewater condensate, $\mathrm{mg} / \mathrm{kg}$. 28

\section{LIST OF FIGURES}

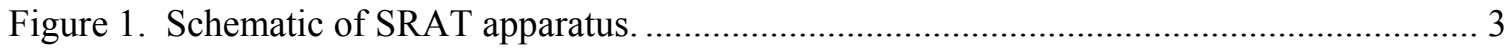

Figure 2. Particle size distribution of SB6-25 and its precursors. ............................................. 6

Figure 3. Yield stress of SB6-25 and comparison to raw simulant, SB6-22, and SB6-23............ 7

Figure 4. Mg and Mn supernate concentrations vs. acid factor, SB6-25 ..................................... 8

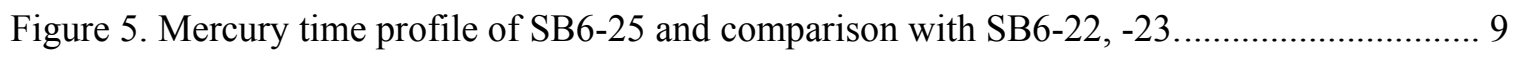

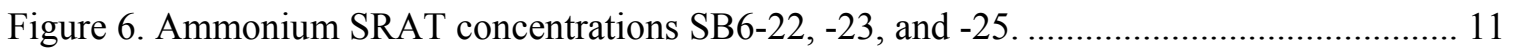




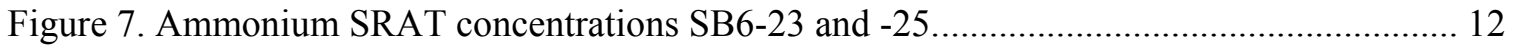

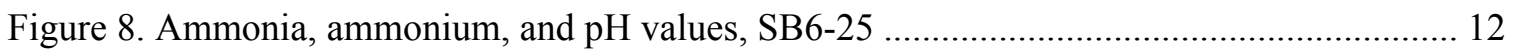

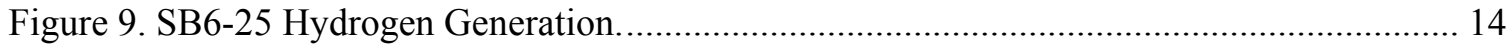

Figure 10. Mg and Mn supernate concentrations vs. acid factor, SB6-26.................................. 15

Figure 11. Mercury time profile of SB6-26 and comparison with SB6-23................................ 16

Figure 12. Mercury in the SRAT product collected from the vessel walls. ............................... 17

Figure 13. Ammonia, ammonium, and pH values, SB6-26 .................................................. 18

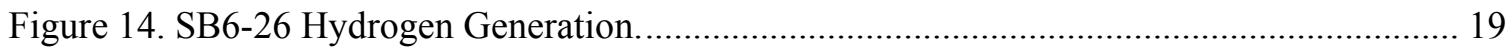

Figure 15. Rheological curve of SB6-25 using double ramp method. ........................................ 22

Figure 16. Rheological curve of SB6-26 using double ramp method .......................................... 22

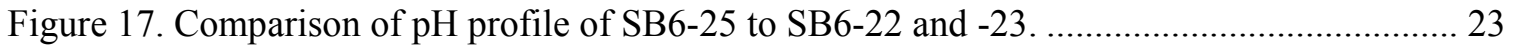

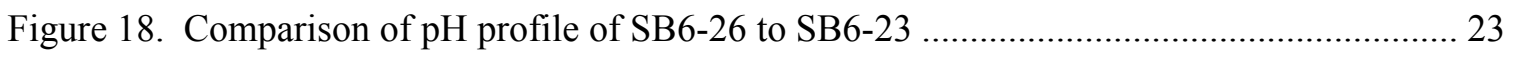

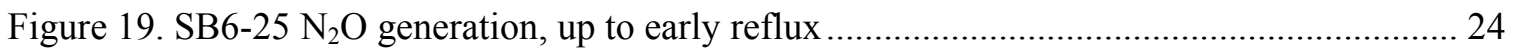

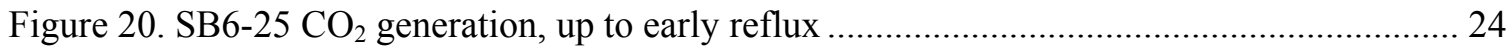

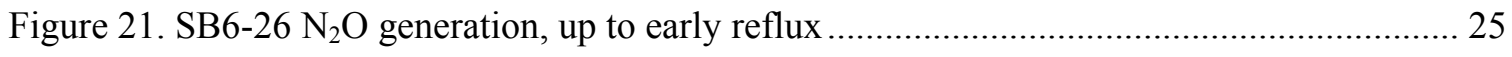

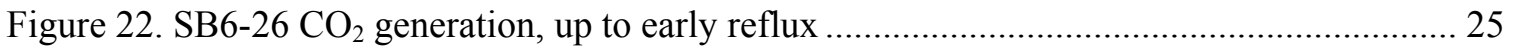




\section{LIST OF ABBREVIATIONS}

$\begin{array}{ll}\text { ACTL } & \text { Aiken County Technology Laboratory } \\ \text { AD } & \text { Analytical Development } \\ \text { AES } & \text { Atomic Emission Spectroscopy } \\ \text { CPC } & \text { Chemical Process Cell } \\ \text { CV } & \text { Cold Vapor } \\ \text { DWPF } & \text { Defense Waste Process Facility } \\ \text { FAVC } & \text { Formic Acid Vent Condenser } \\ \text { IC } & \text { Ion Chromatograph } \\ \text { ICP } & \text { Inductively-Coupled Plasma } \\ \text { MFT } & \text { Melter Feed Tank } \\ \text { MWWT } & \text { Mercury Water Wash Tank } \\ \text { PSAL } & \text { Process Science Analytical Laboratory } \\ \text { SB6-22 } & \text { Sludge Batch 6 run with high acid stoichiometry } \\ \text { SB6-23 } & \text { Sludge Batch 6 run with baseline acid stoichiometry } \\ \text { SB6-25 } & \text { Sludge Batch 6 run pertaining to sheared simulant study } \\ \text { SB6-26 } & \text { Sludge Batch 6 run pertaining to time extension study } \\ \text { SB6-G } & \text { Sludge Batch 6 "G" simulant used for SB6-21 to SB6-26 } \\ \text { SC } & \text { Shielded Cells } \\ \text { SRAT } & \text { Sludge Receipt Adjustment Tank } \\ \text { SRNL } & \text { Savannah River National Laboratory } \\ \text { TT\&QAP } & \text { Task Technical and Quality Assurance Plan } \\ \text { TTR } & \text { Technical Task Request }\end{array}$


SRNL-STI-2010-00307

Revision 0

\subsection{Introduction}

The Defense Waste Processing Facility (DWPF) has transitioned from Sludge Batch 5 (SB5) processing to Sludge Batch 6 (SB6) processing. Phase III-Tank 40 Chemical Process Cell (CPC) flowsheet simulations have been recently completed in order to determine the initial processing conditions for the DWPF transition from SB5 to SB6. ${ }^{1}$

Additional testing was performed to evaluate the impact of two variables on the physical and chemical processes during the Sludge Receipt and Adjustment Tank (SRAT) cycle: a) simulant rheological properties (yield stress) and b) extension of the SRAT cycle time. ${ }^{2}$ The SB6-G simulant that was used for Phase III flowsheet testing was also used for this study. ${ }^{3}$ The higher yield stress SRAT test was conducted at DWPF design rates, $2 \mathrm{gpm}$ acid addition rate and $5000 \mathrm{lb} / \mathrm{hr}$ boil-up rate. By contrast, extension of the cycle time was accomplished by running at DWPF prototypical or nominal operating rates of $1 \mathrm{gpm}$ for formic acid addition and $3000 \mathrm{lb} / \mathrm{hr}$ boil-up rate. The extended run results are compared to a previous baseline SRAT run using the same starting simulant SB6-G, SB6-23 in the Phase III simulant study. The sheared results are compared not only to the baseline simulant work but also to measurements on actual SB6 waste.

Savannah River National Laboratory (SRNL) performed these supplemental runs as requested by Technical Task Request (TTR) ${ }^{2}$ following the guidelines of a Task Technical and Quality Assurance Plan (TT\&QAP) ${ }^{4}$. The R\&D Directions are given in the notebook SRNL-NB-2010-00047.

\subsection{Experimental Procedure}

\subsection{Process and Sample Analytical Methods}

\subsubsection{Experimental Process}

These SRAT experiments were performed in the SRNL facilities within the Aiken County Technology Laboratory (ACTL). As stated above, this study consisted of two SRAT runs; the experiments were conducted concurrently using two 4-L rigs, one for the sheared run, and the other for the time extension or "extended" run. These runs are called SB6-25 and SB6-26, respectively. The equipment is described in an equipment set-up memo ${ }^{5}$, and details of the experimental procedures are given by Procedure ITS00094, Rev. 3 from the L29 manual.

Chemical measurements (off-gas and condensed media compositions and $\mathrm{pH}$ measurements of the slurries) and physical measurements (rheology, particle size distribution, and density) have been performed. The automated data acquisition system developed for the 4-L SRAT rigs was used to collect electronic data on a computer. Collected data included SRAT slurry temperature, bath temperatures for the cooling water to the SRAT condenser and Formic Acid Vent Condenser (FAVC), slurry pH, SRAT mixer speed and torque, and air and helium purge flows (helium is used as an internal standard set to $0.5 \%$ of the nominal SRAT purge air flow). Cumulative acid addition volume data were collected from the automated dispensers using an algorithm that matches the indicated total on the dispenser. Some $\mathrm{pH}$ data were obtained for the nitric acid reservoir that supplied the reflux flow to the ammonia scrubbers. Raw GC chromatographic data were acquired on separate computers dedicated to each instrument.

The chilled off-gas leaving the FAVC was passed through a Nafion dryer in counter-current flow with a dried air stream to reduce the moisture content at the GC inlet. Agilent 3000A micro GCs were used on 
both runs. The GCs were baked out before the runs. Column-A can collect data related to $\mathrm{He}, \mathrm{H}_{2}, \mathrm{O}_{2}, \mathrm{~N}_{2}$, $\mathrm{NO}$, and $\mathrm{CO}$, while column-B can collect data related to $\mathrm{CO}_{2}, \mathrm{~N}_{2} \mathrm{O}$, and water. GC's were calibrated with a standard calibration gas containing 0.499 vol $\% \mathrm{He}, 1.000 \mathrm{vol} \% \mathrm{H}_{2}, 20.00 \mathrm{vol} \% \mathrm{O}_{2}, 51.511 \mathrm{vol} \% \mathrm{~N}_{2}$, $24.49 \mathrm{vol} \% \mathrm{CO}_{2}$ and $2.50 \mathrm{vol} \% \mathrm{~N}_{2} \mathrm{O}$. The calibration was verified prior to starting the SRAT cycle and after completing the SRAT cycle. Room air was used to give a two point calibration for $\mathrm{N}_{2}$.

\subsubsection{Sample Analysis}

Process samples were analyzed by various methods. Slurry and supernate elemental compositions were determined by inductively coupled plasma-atomic emission spectroscopy (ICP-AES) at the Process Science Analytical Laboratory (PSAL). Slurry samples were calcined at $1100^{\circ} \mathrm{C}$. The main advantage of this approach is to permit easier comparisons between SRAT product elements and sludge elements. Noble metals and mercury are trimmed uniquely to each SRAT, and their concentrations are known more accurately from material balance considerations than they could be from ICP-AES analyses. Dewatering condensate samples were sent to PSAL to check for dissolved mercury via ICP-AES.

Supernate (soluble) anions were determined by ion chromatography (IC) on 100-fold weighted dilutions of slurry with water followed by filtration to remove the remaining insoluble solids. The starting sludge was titrated to $\mathrm{pH} 7$ using the PSAL auto-titrator to determine the base equivalents for input into the stoichiometric acid equation. Ammonium ion concentrations were measured from samples of SRAT cycle slurries, SRAT product slurries, SRAT cycle condensates, and ammonia scrubber liquids (see below for scrubber description) by AD using IC.

Slurry and supernate densities were measured by PSAL using the Anton-Parr instrument. For the first time ammonia gas concentrations were measured via a Sensidyne colorimetric gas detector tube system.

Slurry rheology measurements were obtained by using a Haake RS-600 rheometer with the Z41 concentric cylinder geometry. ${ }^{6}$ The rheometer uses a Searle type measuring system, where both speed and torque are measured at the rotating shaft. This was operated in the controlled rate mode for all of the data reported here. Flow curves were obtained by varying the shear rate from 0 to 600 seconds $^{-1}$ over a given time period; measurements of the shear stress were performed.

Particle size analysis was obtained by submitting samples to AD for analysis. Analysis was performed with a Microtrac S3500 Tri-laser Particle Size Analyzer. This apparatus uses angular light scattering principle to measure the particle size distribution. Preparation of the slurry for measurement consists of dilution with water. The particle size distribution can be expressed in terms of a volume distribution, diameter distribution, or area distribution; in this work, the diameter distribution is used.

\subsection{Chemical Process Cell (CPC) Simulation Detail}

Figure 1 shows a schematic of the SRAT apparatus. Details of the SRAT equipment are given elsewhere. ${ }^{5}$ However, information regarding recent additions to the apparatus are discussed here. 


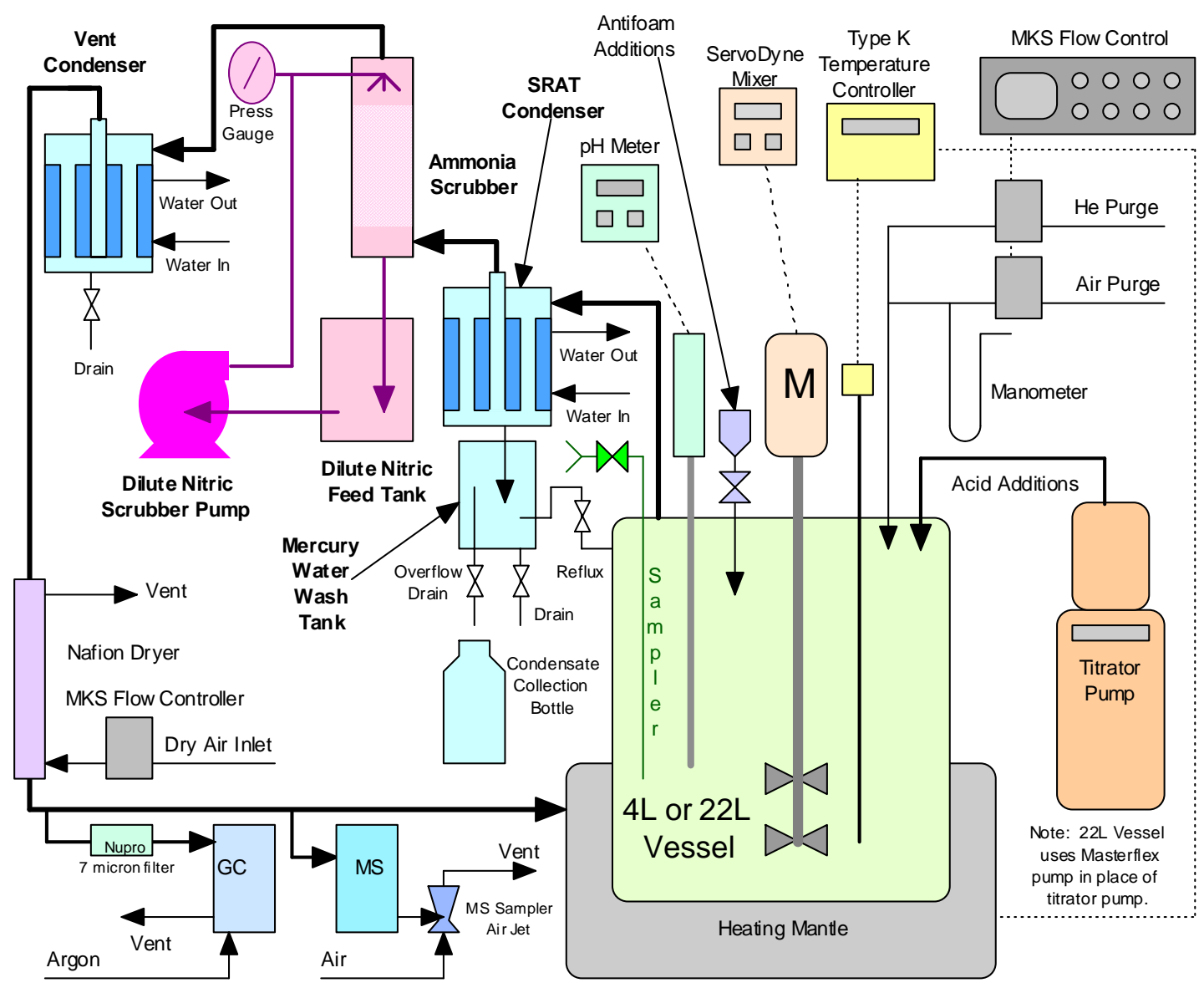

Figure 1. Schematic of SRAT apparatus.

An ammonia gas absorption column (or ammonia scrubber) was recently added to the SRAT apparatus to better simulate the DWPF CPC. The ammonia scrubber used a solution of $749 \mathrm{~g}$ of de-ionized water and $1 \mathrm{~g}$ of $50 \mathrm{wt} \%$ nitric acid. This solution allowed for absorption of ammonia gas, yielding the aqueous ammonium cation, $\mathrm{NH}_{4}{ }^{+}$. The solution was circulated by a Micropump gear pump at about $300 \mathrm{~mL}$ per minute to a spray nozzle at the top of the packed section. The addition of the scrubber to the off-gas system increased the back-pressure on the SRAT vessel and led to an increase in fugitive emissions at the various fittings; thus, water vapor loss increased as well.

\subsection{Acid Stoichiometry}

In order to elucidate the effect of extending the SRAT cycle time, the acid stoichiometric factor of SB626 was set at $113 \%$ based on the Koopman minimum acid equation, ${ }^{7}$ the same as that of the Phase III SRAT study SB6-23, ${ }^{1}$ and the former was compared to the latter. The equivalent Hsu acid stoichiometric factor is $120 \%$. Table 1 compares the stoichiometric factors for the relevant runs considered in this study. In the rest of this paper, only the Hsu factor will be used for consistency. SC-9 is the SB6 qualification SRAT run performed in the SRNL Shielded Cells ${ }^{8,9}$.

The sheared study was concerned primarily with the rheology of both Koopman's baseline run, SB6-23, and with the SC-9 results. The reason for the latter was to understand whether the rheological behavior of 
the simulant parallels that of the real waste. A preliminary part of this study used ultrasonication and dilution to try to match the SB6-G yield stress and weight percent solids with those of the SB6 waste. ${ }^{10}$ This dilution was also applied to the simulant used in this study, SB6-25, but was not taken into account in the acid calculations spreadsheet; thus, the nominal and intended $120 \%$ acid stoichiometry was actually $132 \%$. This factor is bracketed by that of SB6-22 and SB6-23 in the Phase III flowsheet study. Thus, comparisons of SB6-25 were made to both SB6-23 and SB6-22.

Table 1. Acid Stoichiometric Factors

\begin{tabular}{|c|c|c|}
\hline Run ID & Hsu acid factor & $\begin{array}{c}\text { Koopman minimum } \\
\text { acid factor }\end{array}$ \\
\hline SB6-22 & 159 & 150 \\
SB6-23 & 120 & 113 \\
SB6-25 & 132 & 124 \\
SB6-26 & 120 & 113 \\
SC-9 & 115 & 108 \\
\hline
\end{tabular}

\subsection{Other Conditions}

Both new SRAT studies assumed: air purge scaled to $230 \mathrm{scfm}$ in DWPF; a $200 \mathrm{ppm}$ antifoam addition prior to nitric acid addition; a $100 \mathrm{ppm}$ antifoam addition prior to formic acid addition and a $500 \mathrm{ppm}$ antifoam addition prior to boiling; nitric and formic acid additions occurred with the slurry at $93^{\circ} \mathrm{C}$; and reflux followed the dewatering process. A mercury stripping rate of $1 \mathrm{~g} \mathrm{Hg} / 750 \mathrm{~g}$ water evaporated was assumed.

The extended study used slower boiling (during dewatering and reflux) and acid addition rates than the sheared study. In the sheared study, the total SRAT cycle time was about 41 hours but the extended experiment lasted about 57 hours.

The target weight percent of total solids of the SRAT product was lowered to $23 \%$ relative to the $25 \%$ weight solids of SB6-22 and SB6-23 after it was noted ${ }^{1}$ that fugitive water losses in these runs had led to higher than expected solids levels in both the SRAT and SME product slurries. The mercury and noble metal targets for the sludge simulants are shown in Table 2 along with the measured values of the qualification sample.

Table 2. SB6 noble metal and mercury

\begin{tabular}{|l|l|l|l|}
\hline & SC-9 & SB6-25 & SB6-26 \\
\hline $\mathrm{Rh}, \mathrm{wt} \%$ & 0.0187 & 0.0194 & 0.0177 \\
\hline $\mathrm{Ru}, \mathrm{wt} \%$ & 0.0924 & 0.0920 & 0.0845 \\
\hline $\mathrm{Pd}, \mathrm{wt} \%$ & 0.00304 & 0.0031 & 0.0028 \\
\hline $\mathrm{Ag}, \mathrm{wt} \%$ & 0.0138 & 0.0155 & 0.0142 \\
\hline $\mathrm{Hg}, \mathrm{wt} \%$ & 3.12 & 3.0510 & 2.79 \\
\hline
\end{tabular}


SRNL-STI-2010-00307

Revision 0

\subsection{Results and Discussion}

\subsection{Sheared Run, SB6-25}

Ultrasonication was used to increase the yield stress of SB6-G simulant up to $4.5 \mathrm{~Pa}$; this required 30 seconds of ultrasonication at $100 \%$ amplitude $(20 \mathrm{kHz})$. The simulant was intentionally diluted to match the Shielded Cells qualification sample starting solids composition of the qualification sample but, since this dilution was not taken into account, this subsequently increased the acid stoichiometry from $120 \%$ to $132 \%$ and caused a shift in the noble metal and mercury concentrations. Thus, a direct comparison with SB6-22 and SB6-23 is only semi-quantitatively appropriate.

The sheared sludge visibly thickened during formic acid addition. In order to maintain a mixing vortex, the nominal speed of $400 \mathrm{rpm}$ needed to be increased to $550 \mathrm{rpm}$ in the middle of formic acid addition and then was decreased to $500 \mathrm{rpm}$ about $70 \%$ into that acid addition window. This speed was maintained till the end of acid addition and throughout the dewatering. After the first hour of reflux boiling, the mixing speed was then able to be decreased to $400 \mathrm{rpm}$ while maintaining a visible vortex.

\subsubsection{Rheological and particle size results, SB6-25}

The effects of ultrasonication of the simulant and on the SRAT process are discussed here. Particle size distribution measurements were conducted on the raw SB6-G simulant, sheared SB6-G simulant, and on the SRAT product SB6-25. A semi-log plot of the particle size distribution is shown in Figure 2. Raw SB6-G sludge exhibits an approximately log-normal distribution which is common to many particulate solids. ${ }^{11}$ The initial step, ultrasonication, yields the greater difference in distribution while the subsequent SRAT process had a relatively minor impact presumably due to the dissolution and reprecipitation of some of the species. The median particle size values are $7.44 \mu \mathrm{m}, 4.80 \mu \mathrm{m}$, and $4.00 \mu \mathrm{m}$, respectively. The decreasing mean particles size could lead to an increase in yield stress, which is consistent with the rheological measurements, see below. 


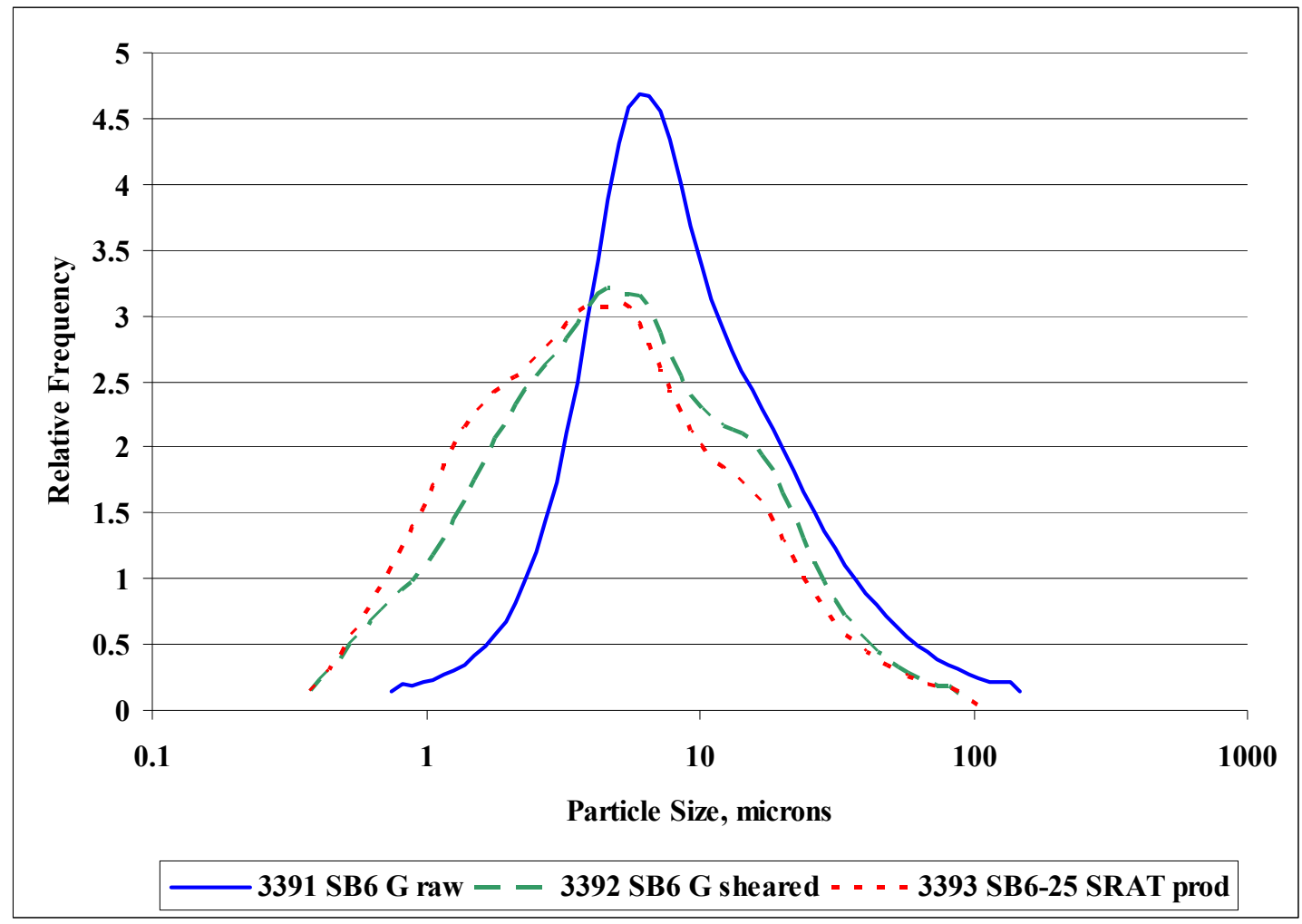

Figure 2. Particle size distribution of SB6-25 and its precursors.

Rheological measurements of SB6-25 SRAT product simulant are compared to those from SB6-22, SB623, and SC-9, see Table 3. Rheological measurements of SB6-G simulant have exhibited time-dependent flow curves and thus a double ramp method was used to find the steady-state yield stress of SB6-25 SRAT product. A rheogram is given by Figure 15 in Appendix A. The initial time dependence was removed by using the second down curve yield stress (steady-state yield stress). For accuracy a second replication was performed and the two results were averaged; the results are shown in Figure 3. Note that the yield stresses of the dilution (to match the Shielded Cells SRAT receipt), baseline, and high acid runs are also shown in the figure. All of the comparisons amongst the simulants are possible since the insoluble solids weight percent levels of the SB6-22, SB6-23, and SB6-25 are fairly close, $14.0 \%, 14.2 \%$, and $12.4 \%$, respectively. Comparison of the SB6-23 and SB6-25 flow curves demonstrate small differences in yield stress and consistency.

Table 3. Rheology of SRAT products, raw simulant and SC-9 


\begin{tabular}{|c|c|c|c|c|c|c|c|}
\hline & $\begin{array}{c}\text { SB6-G } \\
\text { Simulant }\end{array}$ & $\begin{array}{c}\text { SB6-G, } \\
\text { ultrasonicated } \\
\text { Simulant }\end{array}$ & $\begin{array}{c}\text { SB6-25 } \\
\text { SRAT } \\
\text { product }\end{array}$ & $\begin{array}{c}\text { SB6-26 } \\
\text { SRAT } \\
\text { product }\end{array}$ & $\begin{array}{c}\text { SB6-22 } \\
\text { SRAT } \\
\text { product }\end{array}$ & $\begin{array}{c}\text { SB6-23 } \\
\text { SRAT } \\
\text { product }\end{array}$ & $\begin{array}{c}\text { SC-9 } \\
\text { SRAT } \\
\text { product }\end{array}$ \\
\hline $\begin{array}{c}\text { Wt\% total } \\
\text { solids }\end{array}$ & $17.8 \%$ & $17.8 \%$ & $23.0 \%$ & $24.6 \%$ & $25.3 \%$ & $27.0 \%$ & $25.9 \%$ \\
\hline $\begin{array}{c}\text { Wt\% } \\
\text { insoluble } \\
\text { solids }\end{array}$ & $10.9 \%$ & $10.9 \%$ & $12.5 \%$ & $13.0 \%$ & $14.0 \%$ & $14.2 \%$ & $18.3 \%$ \\
\hline \begin{tabular}{c} 
pH \\
\hline $\begin{array}{c}\text { Slurry, } \\
\text { density, } \\
\text { g/mL }\end{array}$
\end{tabular} & 13.2 & 13.2 & 8.1 & 8.2 & 8.5 & 9.3 & 10 \\
\hline $\begin{array}{c}\text { Up yield } \\
\text { stress, Pa }\end{array}$ & N/A & 1.13 & 1.113 & 1.182 & 1.188 & 1.266 & 1.23 \\
\hline $\begin{array}{c}\text { Up } \\
\text { consistency, } \\
\text { cP }\end{array}$ & N/A & 0.5 & 10.4 & 8.5 & 4.7 & 12.0 & N/A \\
\hline $\begin{array}{c}\text { Down yield } \\
\text { stress, Pa }\end{array}$ & 1.6 & 4.4 & 5.6 & 5.2 & 2.6 & 4.2 & 21 \\
\hline $\begin{array}{c}\text { Down } \\
\text { consistency, } \\
\text { cP }\end{array}$ & 7.6 & 7.9 & 11.6 & 9.5 & 7.8 & 12.8 & 15.2 \\
\hline
\end{tabular}

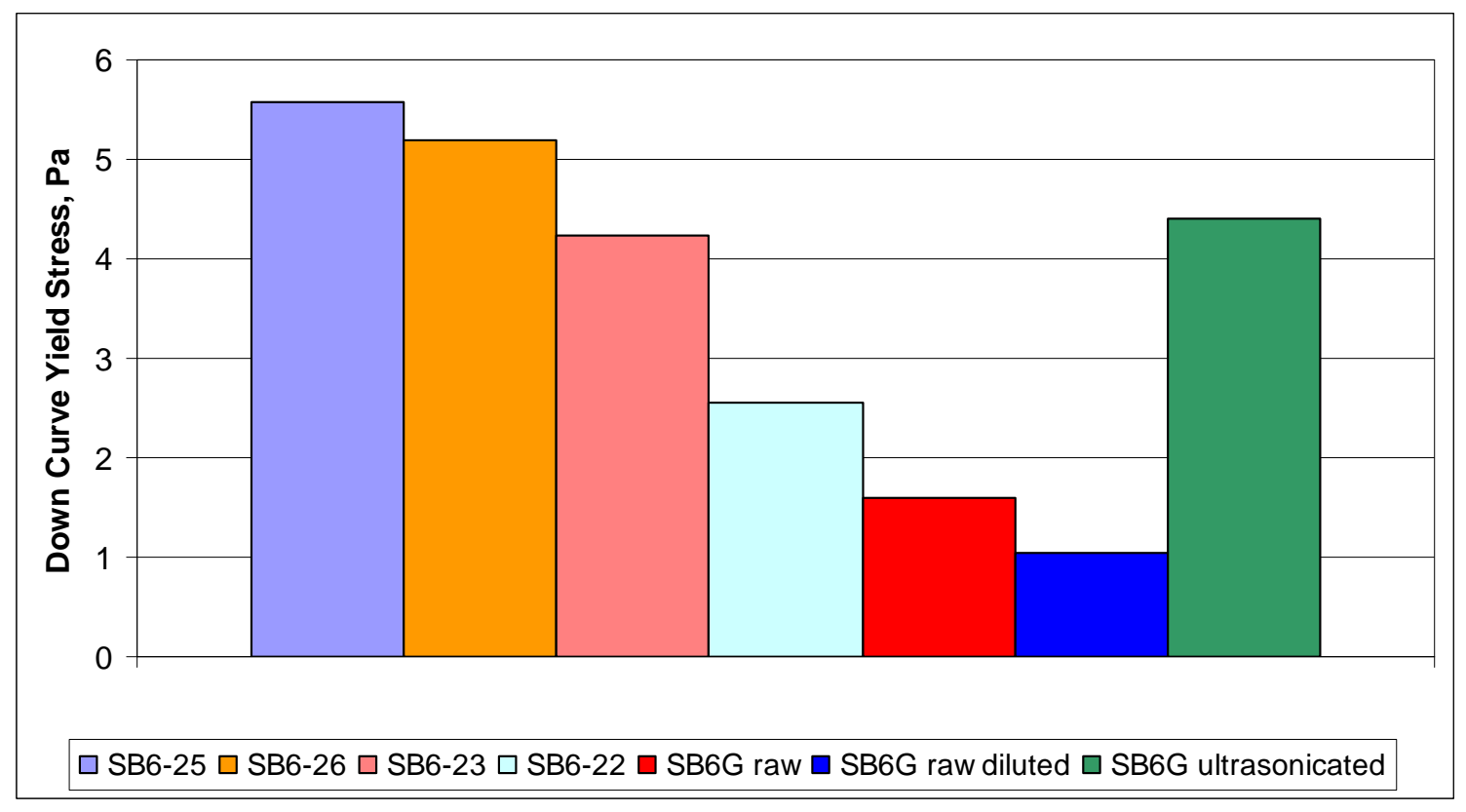

Figure 3. Yield stress of SB6-25 and comparison to raw simulant, SB6-22, and SB6-23.

Dilution of the raw SB6-G sludge predictably caused a decrease in yield stress, in this case from 1.6 down to $1.1 \mathrm{~Pa}$. This sludge was then ultrasonicated to increase the yield stress to about $4.4 \mathrm{~Pa}$ and subsequently underwent the SB6-25 SRAT cycle, resulting in a yield stress of 5.6 Pa. This yield stress is slightly greater than that of the baseline SB6-23 even at lower solids content; this is probably due to a 
smaller particle size distribution. The rheology of the high acid run, SB6-22, shows a markedly smaller yield stress, 2.6 Pa. These observations are consistent with a SME-MFT study which showed that increasing the $\mathrm{pH}$ of a simulant, SB5-6 in that case, caused both an increase in yield stress and an increase of precipitation of magnesium and manganese hydroxides. ${ }^{12}$ Figure 4 shows similar behavior; the supernate concentrations of $\mathrm{Mg}$ and $\mathrm{Mn}$ of the baseline run were smaller (less acid addition yields higher $\mathrm{pH}$ and less dissolution) than those of SB6-25 and SB6-22.

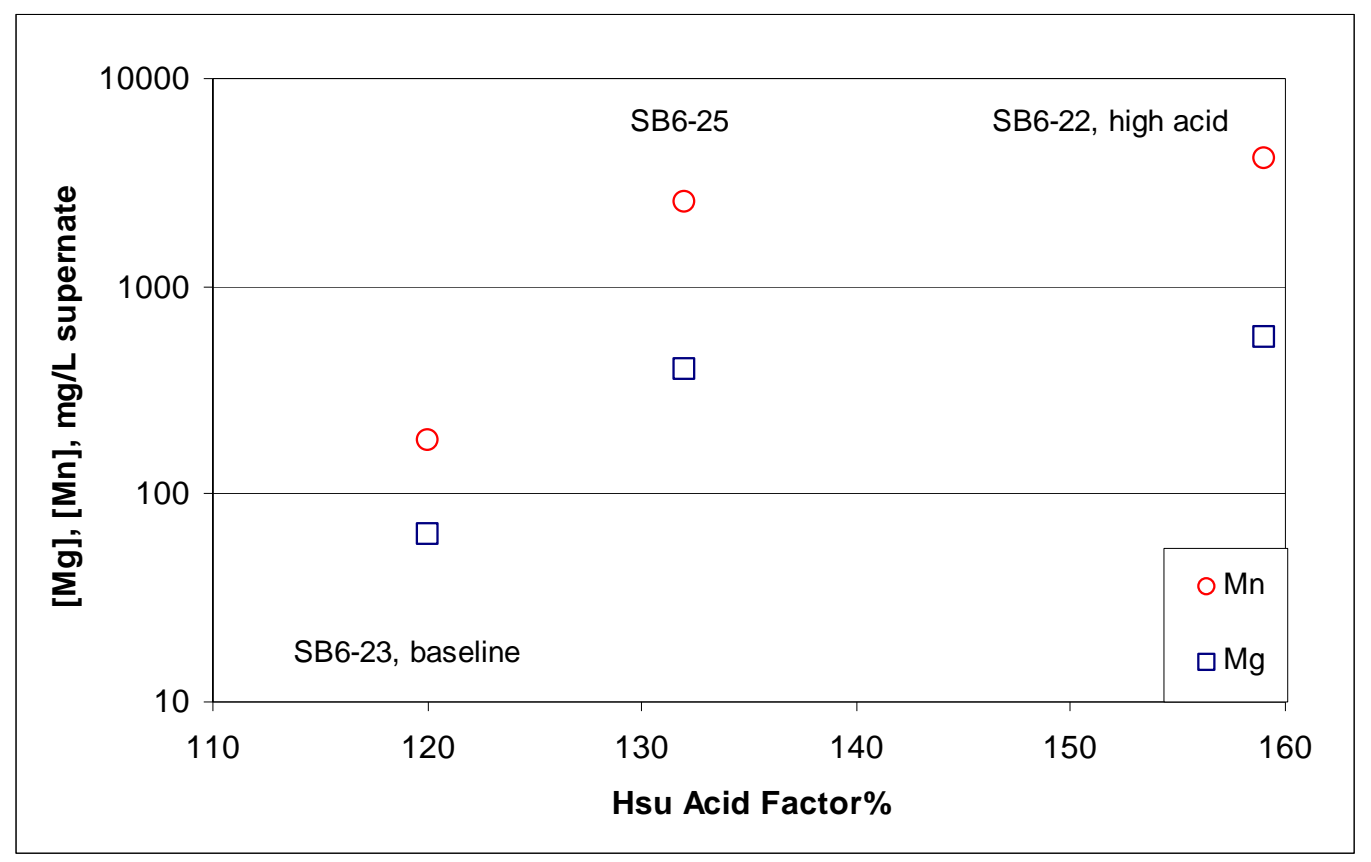

Figure 4. Mg and Mn supernate concentrations vs. acid factor, SB6-25

\subsubsection{Mercury removal, SB6-25}

The actual SB6 waste contains above average mercury concentrations, about $2.8 \mathrm{wt} \%$ in the dried solids; $16.0 \mathrm{~g}$ of yellow $\mathrm{HgO}$ (equivalent to $14.8 \mathrm{~g}$ elemental $\mathrm{Hg}$ ) was trimmed into the simulant before starting the SRAT cycle.

PSAL measurements of the mercury slurry sample concentrations are shown in Figure 5. The mercury concentration in the slurry at the end of reflux was $360 \mathrm{mg} / \mathrm{kg}$ on a slurry basis $(1565 \mathrm{mg} / \mathrm{kg}$ solids basis). The baseline SB6-23 run demonstrated a slow, conventional decrease in $\mathrm{Hg}$ while the high acid run exhibited a faster and more sudden decay. SB6-25 seemed to behave more like the baseline run than the high acid run. 


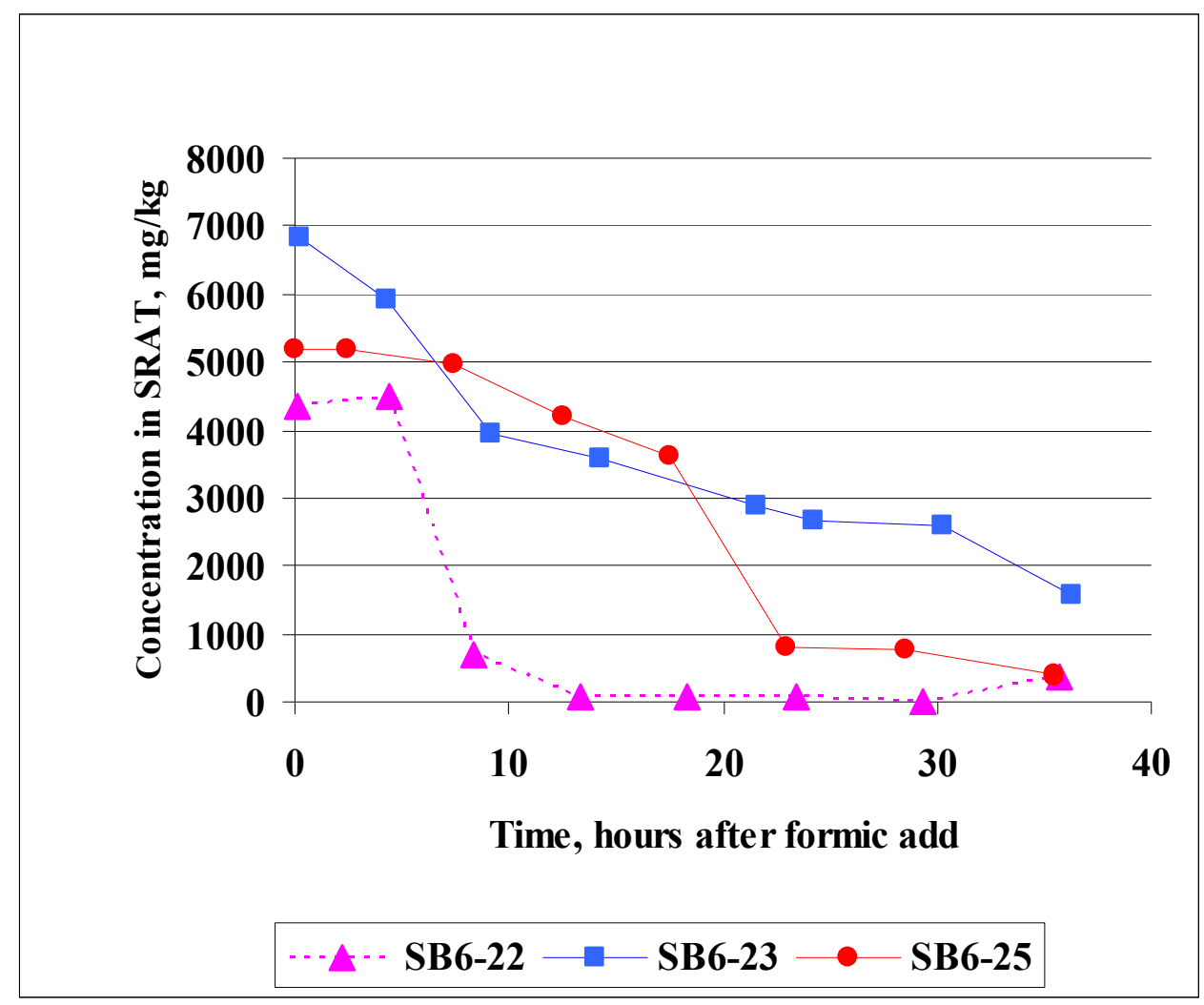

Figure 5. Mercury time profile of SB6-25 and comparison with SB6-22, -23.

SB6-25 was somewhat successful in stripping the mercury. About $11.189 \mathrm{~g} \mathrm{Hg}$ was found in the MWWT as a single, globular entity. The concentration of dissolved mercury in the MWWT was $61.2 \mathrm{mg} / \mathrm{L}$ and $20.7 \mathrm{mg} / \mathrm{L}$ at the end of dewatering and at the end of the SRAT cycle, respectively. Taking into account the mercury trim mass and the compositions of the SRAT dewater, slurry and supernate samples allows for a mass balance of mercury. An estimate of the mass of mercury retained in the SRAT rig is $2.5 \mathrm{~g}$, which occupies a volume of about $0.3 \mathrm{~mL}$. This corresponds to a stripping efficiency of $77 \%$. Because the comparison is not based on an identical acid stoichiometric condition (which increases the uncertainty due to this extra variable), and because the mercury profile shows a behavior that is between the two bracketing studies, there is no evidence that higher yield stress has an unusual effect on the $\mathrm{Hg}$ time profile. There is however, an unusual drop in the apparent concentration of mercury in the SRAT vessel around 20 hours after formic acid addition, see Figure 5. This may be the time at which the mercury became stuck to the inner walls of the vessel. The reason for this or the timing is unknown though it does coincide with rise of ammonium generation in the SRAT, see Section 3.1.3.

\subsubsection{Process sampling results, SB6-25}

The elemental (calcined) slurry and supernate concentrations of SB6-25, SB6-22, and SB6-23 products are given by Tables 12 and 13 in Appendix A. The SB6-25 concentrations do not show much deviation from those of SB6-22 and SB6-23. However, comparing the concentrations of $\mathrm{Mg}$ and $\mathrm{Mn}$ in the supernate of SB6-25 with those of SB6-23 and SB6-22, and cross-referencing with the earlier SME-MFT study $^{12}$ on the effects of $\mathrm{pH}$ on rheology confirms that these supernate species concentrations have an indirect relation with $\mathrm{pH}$. That is, the addition of acid dissolves more of the $\mathrm{Mg}(\mathrm{OH})_{2}$ and $\mathrm{MnO}_{2}$. The 
anion concentrations of SRAT products are shown in Table 4. In all cases, the nitrite was completely destroyed since none could be detected. The anion concentrations of SB6-25 slurry at one-half hour from the end of reflux and at the end of acid addition are depicted in Tables 14 and 15, respectively, of Appendix A. There is good agreement between the anion concentrations one half hour before the end of reflux and at the end of reflux, as expected. The elemental concentrations in the slurry at the end of acid addition are given by Table 16, respectively. Finally, the composite anion composition of the MWWT condensate during dewatering is shown in Table 17. These tables do not indicate that the SB6-25 run behaves anomalously relative to the bracketing studies. Thus, it is not likely that a higher yield stress makes a large difference in SRAT cycle behavior.

Table 4. Anion composition of SRAT products, $\mathrm{mg} / \mathrm{kg}$ slurry

\begin{tabular}{|c|c|c|c|c|}
\hline Element & $\begin{array}{c}\text { SB6-25 SRAT } \\
\text { product }\end{array}$ & $\begin{array}{c}\text { SB6-26 SRAT } \\
\text { product }\end{array}$ & $\begin{array}{c}\text { SB6-22 SRAT } \\
\text { product }\end{array}$ & $\begin{array}{c}\text { SB6-23 SRAT } \\
\text { product }\end{array}$ \\
\hline $\mathrm{F}^{-}$ & $<100$ & $<100$ & $<100$ & $<100$ \\
\hline $\mathrm{Cl}^{-}$ & 458 & 441 & 600 & 550 \\
\hline $\mathrm{NO}_{2}^{-}$ & $<100$ & $<100$ & $<90$ & $<90$ \\
\hline $\mathrm{NO}_{3}^{-}$ & 27000 & 27550 & 26300 & 28000 \\
\hline $\mathrm{SO}_{4}^{-2}$ & 498 & 420 & 520 & 640 \\
\hline $\mathrm{HCO}_{2}^{-}$ & 49600 & 51800 & 40000 & 41800 \\
\hline $\mathrm{PO}_{4}^{-3}$ & $<100$ & $<100$ & $<100$ & $<100$ \\
\hline
\end{tabular}

The predicted redox value based on the SRAT product anion concentrations is given in Table 5; data for the other runs are also given for comparison. Because these runs were performed using the same simulant and under similar conditions, these redox values all are similar to each other; however, these are half of the target value which indicates that more formate was destroyed than predicted and more reductant was needed (i.e., increase formic acid to nitric acid ratio).

Table 5. Predicted redox in glass.

\begin{tabular}{|c|c|}
\hline Run ID & Predicted $\mathbf{F e}^{+2} / \mathbf{\Sigma F e}$ \\
\hline SB6-22 & 0.110 \\
SB6-23 & 0.115 \\
SB6-25 & 0.093 \\
SB6-26 & 0.104 \\
\hline
\end{tabular}

Ammonium concentrations have also been measured in the SRAT slurry. While Figure 6 compares $\left[\mathrm{NH}_{4}{ }^{+}\right]$for all three experiments, SB6-22 is left out of Figure 7 because its values are higher and the large scale dwarfs the other two. Ammonium concentration measurements were made during the time periods that ammonium formation was observed during SB6-23 processing. The three time profiles are similar; while SB6-22 has the highest ammonium concentrations, all three runs exhibit peak values around 22 to 26 hours after the end of formic acid addition.

Ammonia had been detected in the off-gas system by Koopman, ${ }^{13}$ thus justifying the installation of an ammonia scrubber to the SRAT apparatus. IC measurements of $\mathrm{NH}_{4}{ }^{+}$in the FAVC condensate, which is downstream of the scrubber and upstream of the Nafion dryer, showed negligible ammonium ion in the condensate despite the presence of large concentrations of $\mathrm{NH}_{3}$ and $\mathrm{NH}_{4}{ }^{+}, 925 \mathrm{ppm}$ (just upstream of the scrubber) and $934 \mu \mathrm{g} / \mathrm{mL}$ (in scrubber solution), respectively; thus, it can be concluded that the ammonia scrubber worked efficiently. 
Measurements were performed of the concentrations of ammonia just upstream of the ammonia scrubber and of the ammonium cation captured in the recirculating liquid used to reflux the scrubber. It seems that when the $\mathrm{pH}$ curve approaches neutral values (about 6.14 at boiling ${ }^{14}$ ), $\left[\mathrm{NH}_{4}{ }^{+}\right]$is initially produced in the slurry. Once ammonia gas is emitted, $\left[\mathrm{NH}_{4}{ }^{+}\right]$becomes evident in the scrubber liquid. Measurements of ammonium in the FAVC downstream of the scrubber yielded values lower than the detection limit. Thus, the scrubber effectively absorbed the ammonia evolved from the SRAT. The pH profile itself is compared to those of SB6-23 and SB6-22 in Appendix A, Figure 17. As expected, the SB6-25 pH readings were bracketed by SB6-23 and SB6-22.

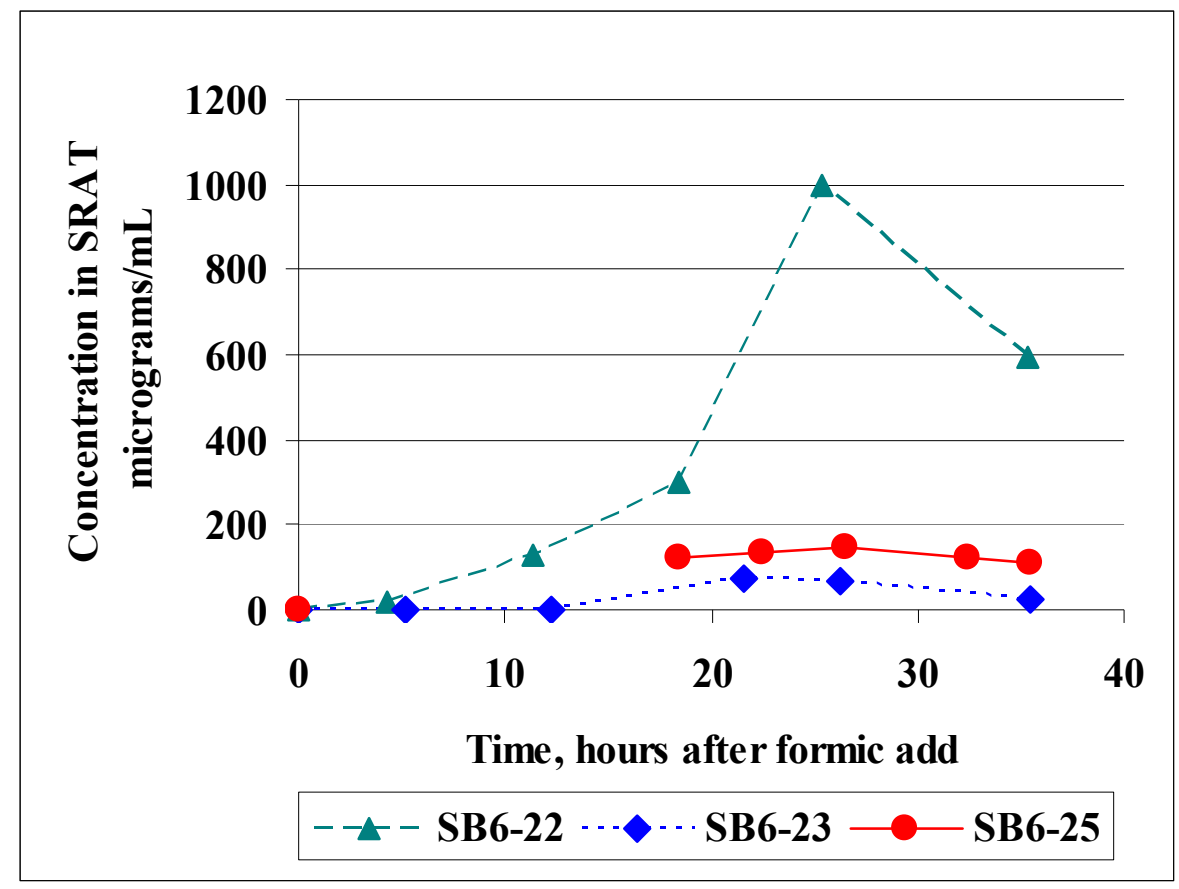

Figure 6. Ammonium SRAT concentrations SB6-22, -23, and -25. 


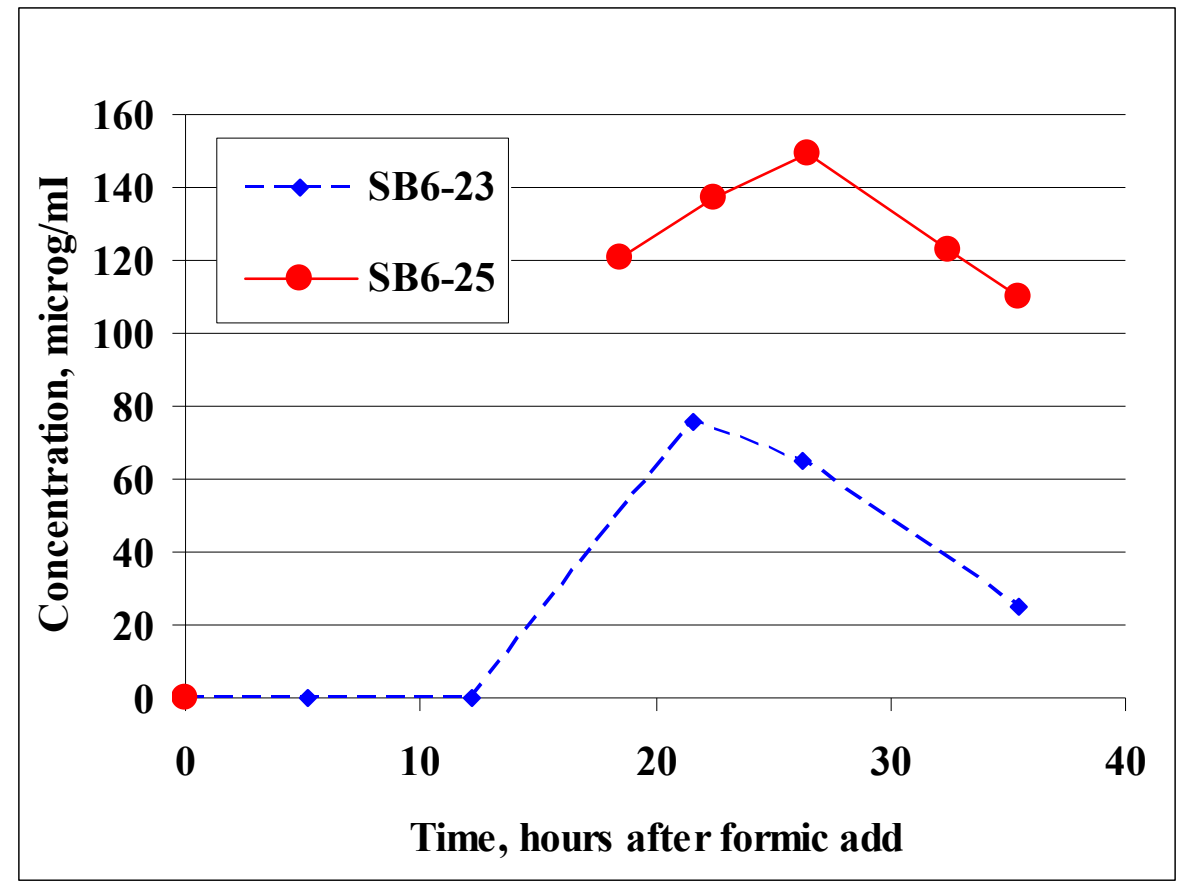

Figure 7. Ammonium SRAT concentrations SB6-23 and -25.

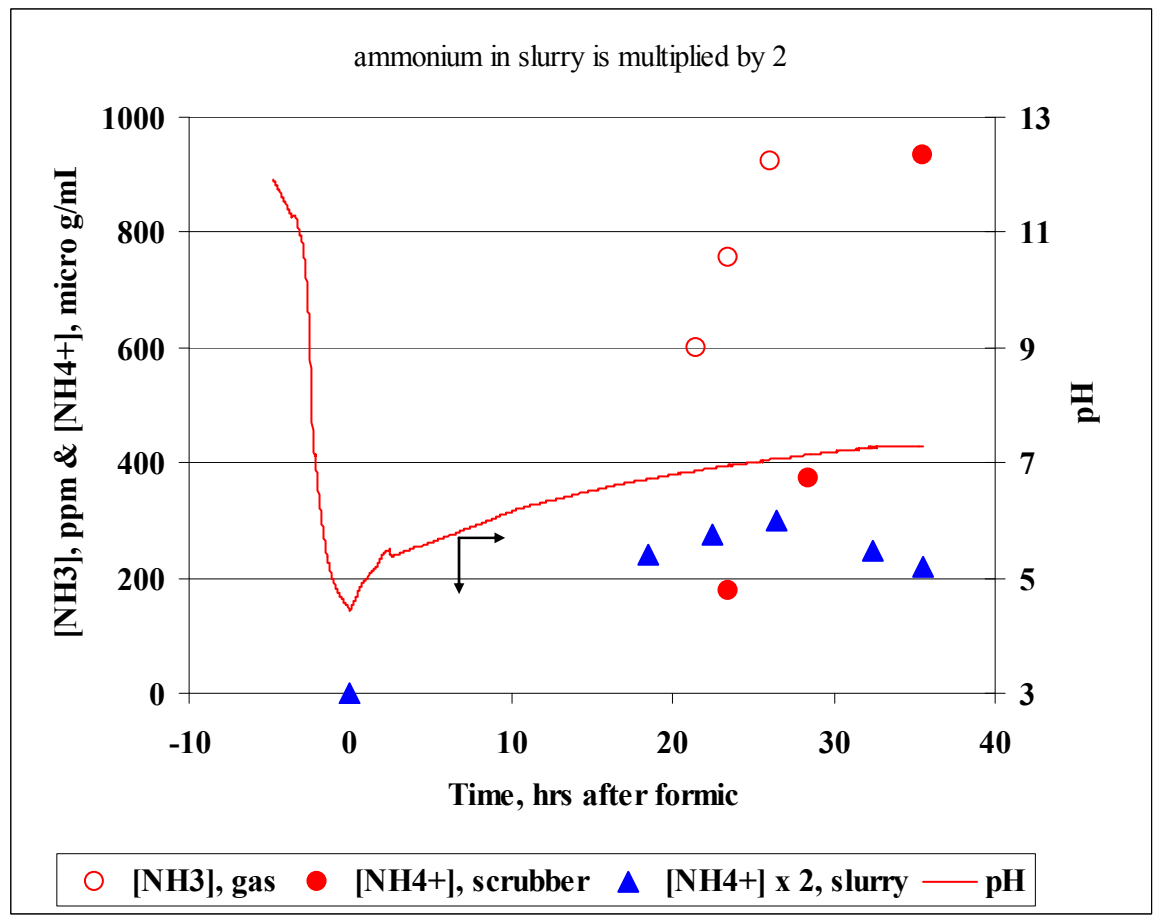

Figure 8. Ammonia, ammonium, and pH values, SB6-25

The SRAT product anions were used to determine the percent formate loss, percent nitrite loss, and the net nitrite-to-nitrate conversion for the SRAT cycle. These quantities are given in Table 6. Formate loss is the difference between the number of moles of SRAT product formate and moles of formic acid added, 
divided by moles of formic acid added. Nitrate gain/loss is the number of moles of SRAT product nitrate minus all sources of nitrate addition (excluding nitrite-to-nitrate conversion), divided by the sources of nitrate addition. The SB6-25 product nitrite concentration was below detection limits in the slurry, see Table 4. The lower formate loss in SB6-25 relative to SB6-23 was unexpected, since the run had a higher acid stoichiometry and higher noble metal concentrations. A potential off-setting factor was the greater dilution of reagents in SB6-25 relative to SB6-23.

Table 6. SRAT cycle anion reactions, SB6-25

\begin{tabular}{|c|c|c|c|c|c|c|}
\hline Run & $\begin{array}{c}\text { Acid, Hsu } \\
\text { eq }\end{array}$ & $\begin{array}{c}\text { Nitrite } \\
\text { Loss }\end{array}$ & $\begin{array}{c}\text { Net } \\
\text { Nitrite-to- } \\
\text { Nitrate }\end{array}$ & $\begin{array}{c}\text { Nitrate } \\
\text { gain/(loss) }\end{array}$ & $\begin{array}{c}\text { Formate } \\
\text { Loss }\end{array}$ & $\begin{array}{c}\text { Formate } \\
\text { Lost, } \mathbf{g}\end{array}$ \\
\hline SB6-22 & $159 \%$ & $>99.5 \%$ & $-15 \%$ & $(11 \%)$ & $58 \%$ & 153 \\
\hline SB6-23 & $120 \%$ & $>99.5 \%$ & $9 \%$ & $8 \%$ & $46 \%$ & 93 \\
\hline SB6-25 & $132 \%$ & $>99.5 \%$ & $17 \%$ & $14 \%$ & $32 \%$ & $73 \dagger$ \\
\hline
\end{tabular}

$\dagger$ the formate lost value of SB6-25 is scaled up to a $3200 \mathrm{~g}$ basis for better comparison with the other runs; the original value is $60 \mathrm{~g}$.

\subsubsection{Off-gas results, SB6-25}

Gas chromatography was used to analyze the composition of the off-gas downstream of the chilled condenser (FAVC). SRAT cycle hydrogen data are given in Figure 9. Because hydrogen generation is sensitive to acid stoichiometry, the SB6-25 data are compared to those of SB6-22 and SB6-23. The acid stoichiometries are $132 \%, 159 \%$, and $120 \%$, respectively. The sheared run exhibits hydrogen generation behavior that is intermediate; the initial peak is earlier and greater than that of the baseline and later and lower than the high acid run. All three runs show a "shoulder" before the first peak but only SB6-22 exhibits a second, higher peak later in the SRAT cycle. Table 7 shows the maximum observed gas generation rates, including hydrogen. The peak value for SB6-25 is much closer to the baseline than to the high acid run. Table 8 gives the total masses generated over the entire SRAT cycle. The mass of hydrogen generated by SB6-25 is between the bracketing runs.

SRAT cycle $\mathrm{N}_{2} \mathrm{O}$ and $\mathrm{CO}_{2}$ data are depicted by Figures 19 and 20, respectively, in the appendix. The nitrous oxide generation of SB6-25 is more similar to SB6-23 than to the high acid run. SB6-25 produced less $\mathrm{N}_{2} \mathrm{O}$ than SB6-23 (both peak and total mass comparisons), see Tables 7 and 8; this implies that the shearing may have had a mitigating effect on $\mathrm{N}_{2} \mathrm{O}$ generation. The maximum $\mathrm{CO}_{2}$ generation was bounded by the bracketing values but the total mass was slightly less than the baseline value. 


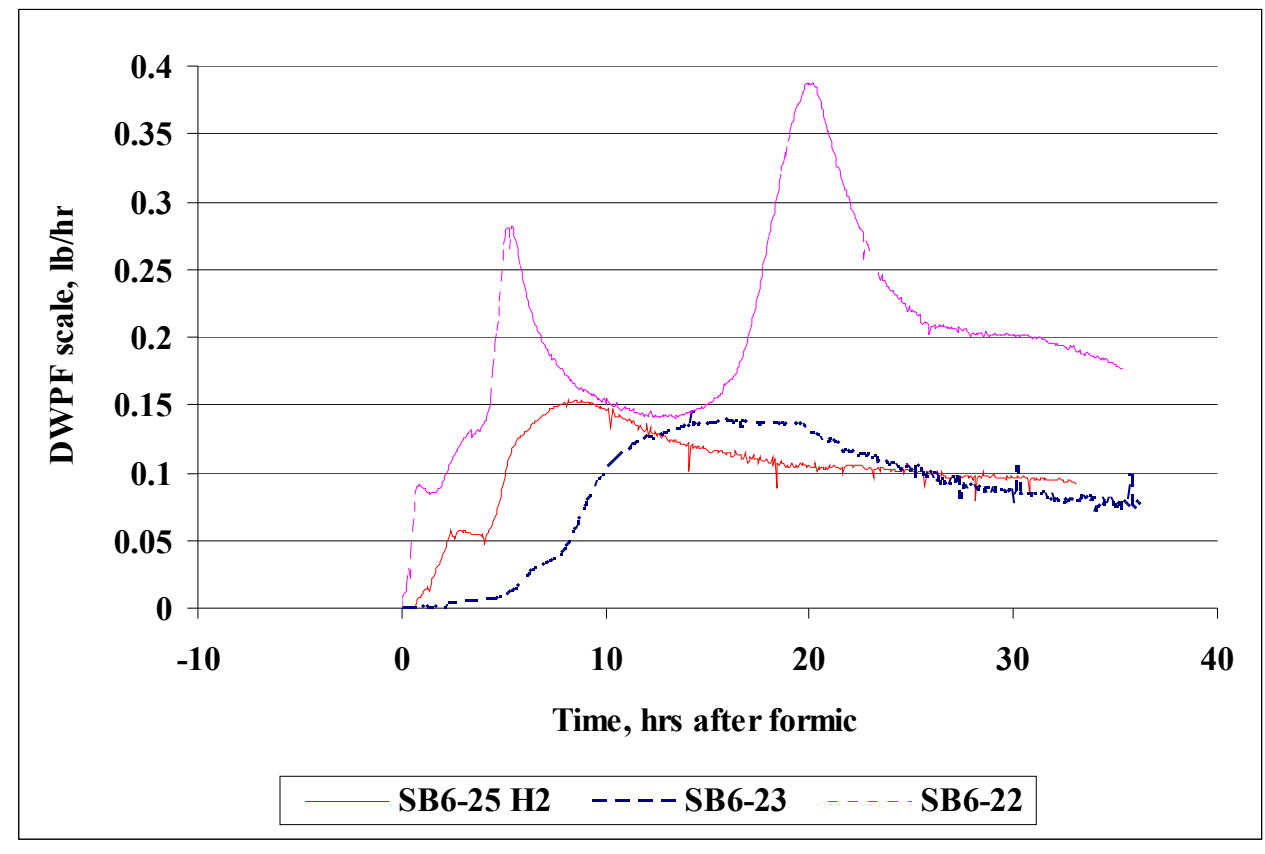

Figure 9. SB6-25 Hydrogen Generation.

Table 7. Maximum observed gas generation rates, SB6-25

\begin{tabular}{|c|c|c|c|c|}
\hline Gas & $\begin{array}{c}\text { SB-22, DWPF } \\
\mathbf{l b} / \mathbf{h r}\end{array}$ & $\begin{array}{c}\text { SB6-23, DWPF } \\
\mathbf{l b} / \mathbf{h r}\end{array}$ & $\begin{array}{c}\text { SB6-25, DWPF } \\
\mathbf{l b} / \mathbf{h r}\end{array}$ & $\begin{array}{c}\text { SC-9, DWPF } \\
\mathbf{l b} / \mathbf{h r}\end{array}$ \\
\hline $\mathrm{H}_{2}$ & 0.39 & 0.15 & 0.15 & 0.55 \\
\hline $\mathrm{N}_{2} \mathrm{O}$ & 28 & 21 & 16 & 17.2 \\
\hline $\mathrm{CO}_{2}$ & 550 & 620 & 610 & 506 \\
\hline
\end{tabular}

Table 8. Total masses generated, DWPF scale, SB6-25

\begin{tabular}{|c|c|c|c|}
\hline Gas & SB-22, lb & SB6-23, lb & SB6-25, lb \\
\hline $\mathrm{H}_{2}$ & 7.04 & 3.07 & 3.47 \\
\hline $\mathrm{N}_{2} \mathrm{O}$ & 65.7 & 41.6 & 29.1 \\
\hline $\mathrm{CO}_{2}$ & 1886 & 1381 & 1322 \\
\hline
\end{tabular}

\subsection{Extended Run, SB6-26}

The extended time run, SB6-26, was conducted under conditions identical to that of SB6-23 ${ }^{1}$ except for two parameters; the formic acid DWPF-scale flow rate was reduced from $2 \mathrm{gpm}$ down to $1 \mathrm{gpm}$ and the DWPF-scale SRAT boil-up rate was reduced from $5,000 \mathrm{lb} / \mathrm{hr}$ to $3,000 \mathrm{lb} / \mathrm{hr}$. The acid stoichiometry was held at $120 \%$ or 1.85 mol per liter of SRAT receipt slurry. The mixing speed was constant at $400 \mathrm{rpm}$ throughout the whole SRAT cycle. 


\subsubsection{Rheological and particle size results, SB6-26}

The down curve yield stresses of SB6-26 and SB6-23 are 5.2 Pa and 4.2 Pa, respectively, as shown above in Table 3, while the consistencies were 9.5 and $12.8 \mathrm{cP}$ respectively. Figure 16 in the appendix shows an example of one of the two double ramp rheograms used to obtain the yield stress of the SB6-26 SRAT product. The higher yield stress of SB6-26 was effectively negated by the lower consistency, and there was little rheological difference between the actual flow curves of the two products. However, the insoluble weight percent (total weight $\%$ also) was slightly lower at 13.0\% for SB6-26 than for SB6-23 at $14.2 \%$, as shown in Table 3. It is possible that the rheology-thinning effects of lower solids weight percentages could have been negated by the longer mixing time which subsequently could have contributed to both a decreased particle size distribution and more dissolution of oxides of $\mathrm{Mg}$ and $\mathrm{Mn}^{12}$ (see Figure 10).

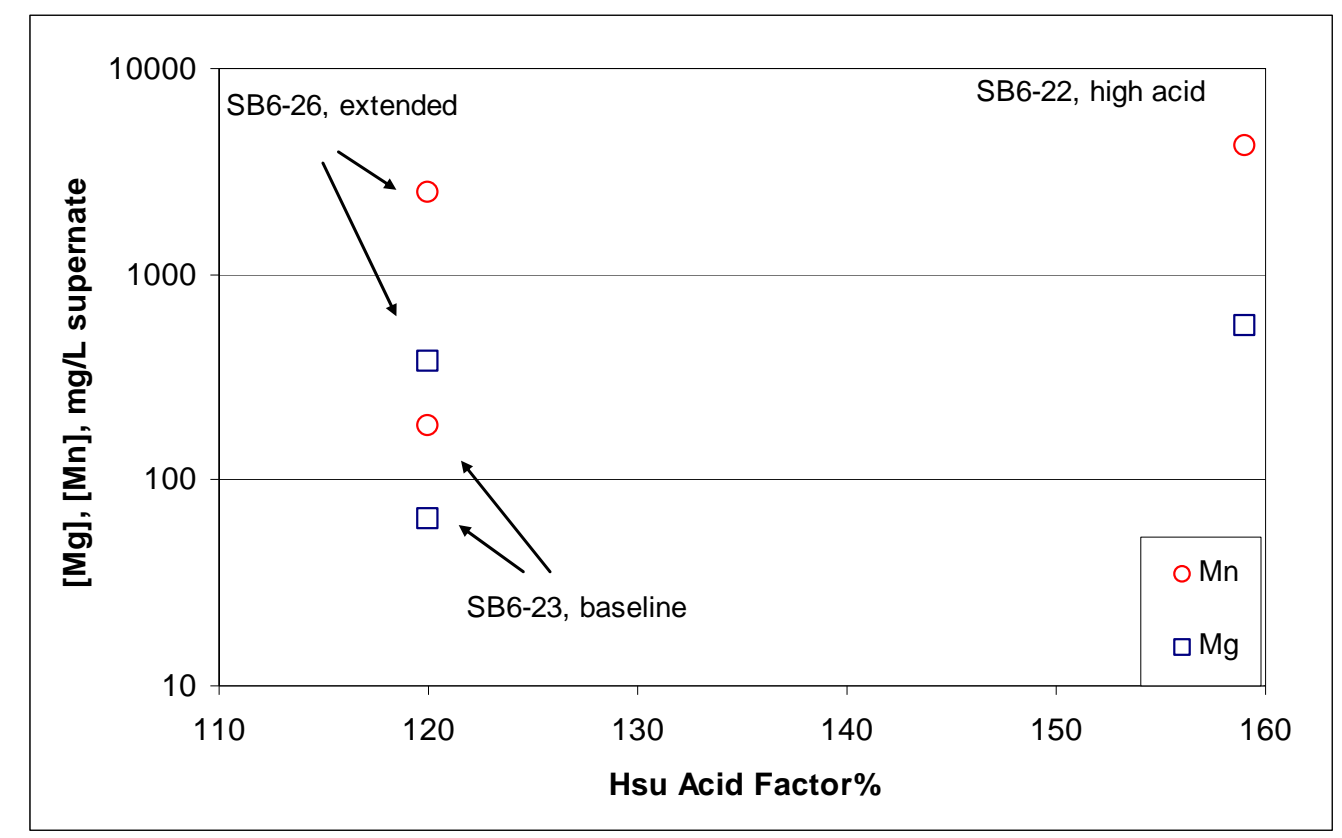

Figure 10. Mg and Mn supernate concentrations vs. acid factor, SB6-26

\subsubsection{Mercury removal, SB6-26}

PSAL measurements of the SRAT slurry mercury sample concentrations are given in Figure 11. Relative to SB6-26, the baseline run demonstrated a slower, conventional $\mathrm{Hg}$ decay that is associated with steam stripping. The SB6-26 mercury profile exhibits a sudden and dramatic decrease between 3 and 10 hours; the concentration in the sludge was $61.3 \mathrm{mg} / \mathrm{kg}$ at the end of reflux. This decrease is earlier and more acute than that exhibited by SB6-25 but is similar in magnitude to that of SB6-22 (Figure 5). 


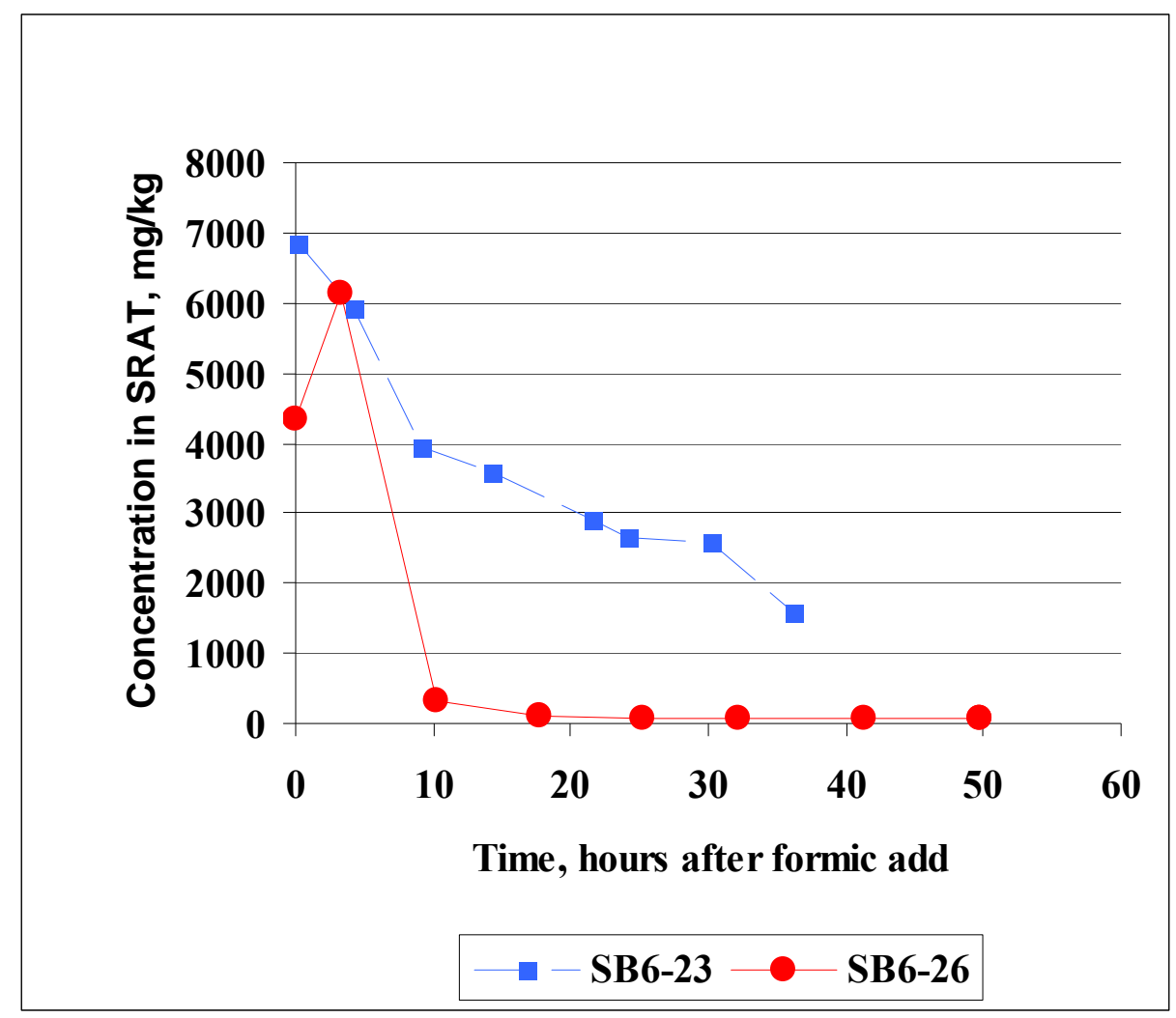

Figure 11. Mercury time profile of SB6-26 and comparison with SB6-23.

This dramatic decrease is not an indication of successful steam stripping. Measurements of the mercury content in the initial and final composite dewater of the MWWT (both aqueous and elemental) and in the sludge allow for a mass balance, which was used to estimate the amount of mercury that was missing. Out of the $16.4 \mathrm{~g}$ of elemental $\mathrm{Hg}$ that was trimmed, only about $4.3 \mathrm{~g}$ was found in the MWWT as elemental Hg. The rest is very likely to have been retained in the SRAT rig, though none was found sticking to the impeller or the shaft. Based on visual observations, the sticky slurry that could not be easily poured out of the SRAT rig at the end of the experiment likely contained the missing mercury, see Figure 12. This picture shows fairly large globules of elemental mercury in the tray, and these were not likely to have been suspended and detected during slurry sampling. The mass balance indicates that up to about $11.8 \mathrm{~g}$ of $\mathrm{Hg}$ was retained on the inner walls of the SRAT rig; this would correspond to a volume of about $0.9 \mathrm{~mL}$ and a $27 \%$ stripping efficiency for the overall process. It seems that cycle time extension can prevent mercury from being stripped. 


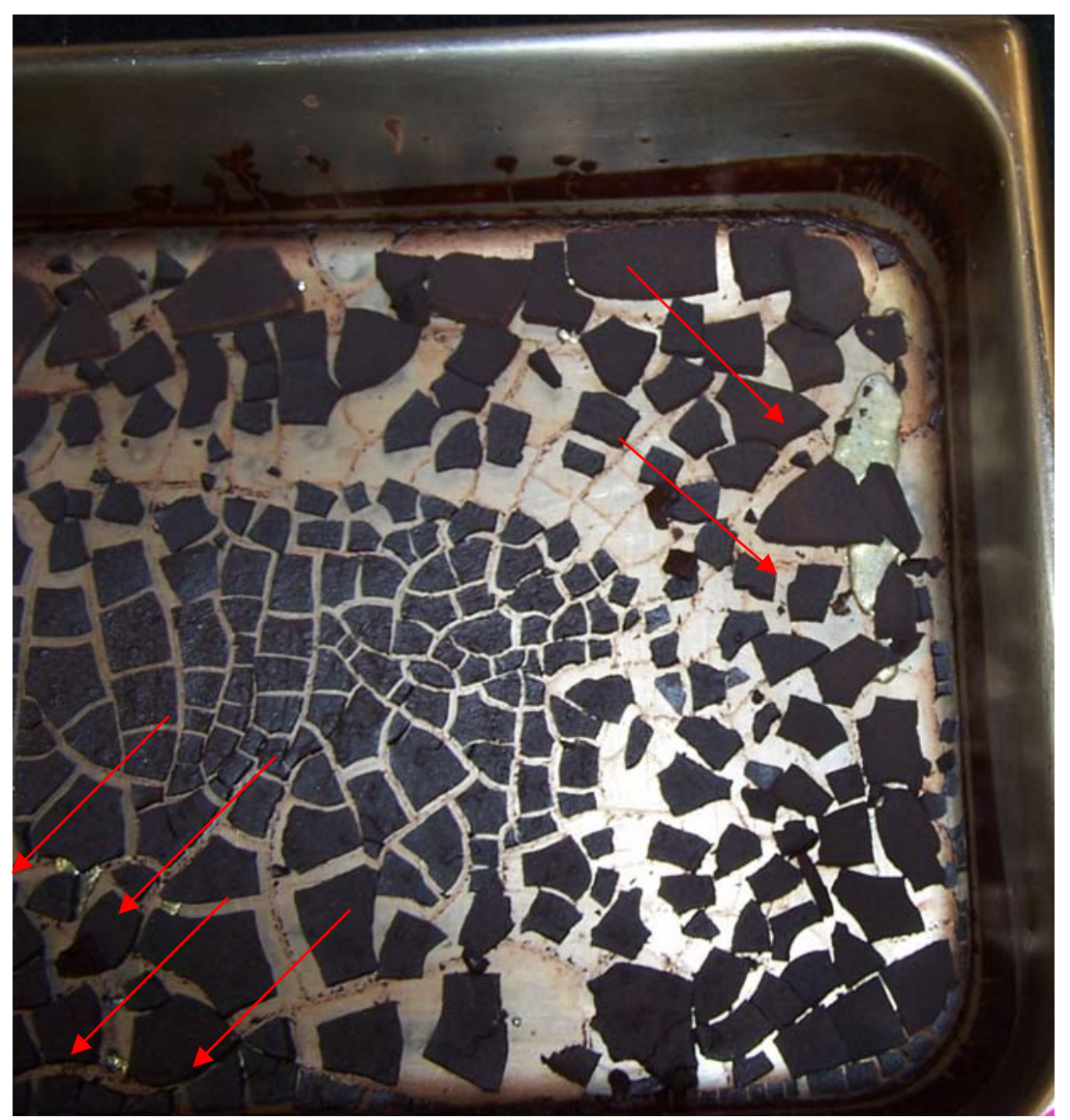

Figure 12. Mercury in the SRAT product collected from the vessel walls.

\subsubsection{Process sampling results, SB6-26}

Tables 4 (above) and 12 through 17 in the appendix show concentrations of SB6-26 runs in both phases and at various times (end of acid addition, end of dewatering, and at the end of the cycle); these tables were introduced for SB6-25 data in Section 3.1.3. There is good agreement between the anion concentrations one half hour before the end of reflux and at the end of reflux, as expected. None of the SB6-26 elemental concentrations show significant deviation from those of SB6-23. Like SB6-25, ammonium concentrations in the slurry were also measured for SB6-26 but were too low to be detected. However, concentrations of the ammonia gas upstream of the ammonia scrubber and also the concentration of ammonium in the scrubber absorption fluid were measurable, see Figure 13. Again, as the $\mathrm{pH}$ reached neutrality, the ammonia and ammonium concentrations in the off-gas system rose to measurable levels. These results can be compared to the SB6-23 ammonium concentration in the scrubber, $1520 \mu \mathrm{g} / \mathrm{L}$; this value is more than nine times larger than largest value of SB6-26, $165 \mu \mathrm{g} / \mathrm{L}$. The process that produces ammonium in the scrubber seems to depend on the acid addition rate.

The $\mathrm{pH}$ profile is compared to those of SB6-23 in Appendix A, Figure 18. The $\mathrm{pH}$ of SB6-26 was lower than that of the baseline run SB6-23; this behavior is reminiscent of a somewhat greater acid stoichiometry condition, such as SB6-25. The predicted redox values are discussed and are shown above in Table 5. Finally, the nitrite-to-nitrate conversion and losses of nitrite, nitrate, and formate are given in Table 9. SB6-26 exhibited less loss of formate than in the baseline, see Tables 4 and 9, but all of the nitrite has been removed. SB6-26 produced slightly more $\mathrm{CO}_{2}$, so there may be some analytical issues with the formate data. 


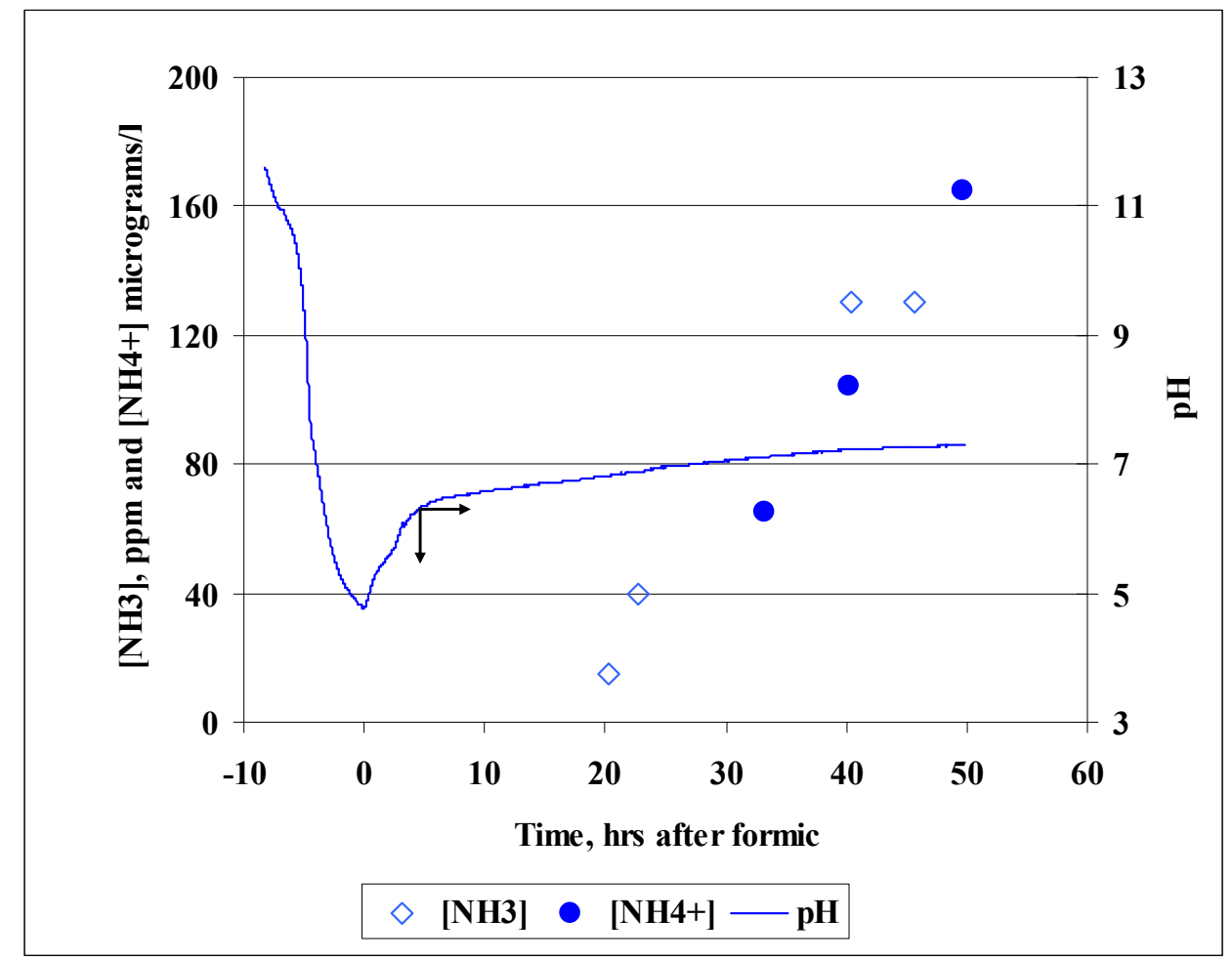

Figure 13. Ammonia, ammonium, and pH values, SB6-26

Table 9. SRAT cycle anion reactions, SB6-26

\begin{tabular}{|c|c|c|c|c|c|c|}
\hline Run ID & $\begin{array}{c}\text { Acid Hsu } \\
\text { eq }\end{array}$ & $\begin{array}{c}\text { Nitrite } \\
\text { Loss }\end{array}$ & $\begin{array}{c}\text { Net } \\
\text { Nitrite-to- } \\
\text { Nitrate }\end{array}$ & $\begin{array}{c}\text { Nitrate } \\
\text { gain/(loss) }\end{array}$ & $\begin{array}{c}\text { Formate } \\
\text { Loss }\end{array}$ & $\begin{array}{c}\text { Formate } \\
\text { Lost, }\end{array}$ \\
\hline SB6-23 & $120 \%$ & $>99.5 \%$ & $9 \%$ & $8 \%$ & $46 \%$ & 93 \\
\hline SB6-26 & $120 \%$ & $>99.5 \%$ & $12 \%$ & $17 \%$ & $26 \%$ & 53 \\
\hline
\end{tabular}

\subsubsection{Off-gas results, SB6-26}

SRAT cycle hydrogen data are given in Figure 14, scaled to DWPF lbs/hr. It is clear that the extended run had a lower maximum generation rate, Table 10, and produced much less hydrogen overall, Table 11. It is likely that the slower acid addition (lower acid concentration) could have impacted the nitrite destruction and this in turn could have affected the hydrogen generation rate.

SRAT cycle $\mathrm{N}_{2} \mathrm{O}$ and $\mathrm{CO}_{2}$ data are depicted by Figures 19 and 20, respectively, in the appendix. As with the hydrogen generation, Table 10 gives the maximum generation rates of $\mathrm{N}_{2} \mathrm{O}$ and $\mathrm{CO}_{2}$ and Table 11 gives the total masses generated throughout the cycle; comparisons are made to the baseline run, SB6-23. The extended run $\mathrm{N}_{2} \mathrm{O}$ peak generation rate was one-half of that exhibited by SB6-23; however, the total mass generated was only about $17 \%$ below the baseline. The $\mathrm{CO}_{2}$ profiles indicate a tradeoff: the extended run had a significantly lower peak generation rate (36\% less) but a larger total mass ( $6 \%$ more). It is also clear that while the $\mathrm{CO}_{2}$ peak occurred two hours before that of the baseline, both $\mathrm{N}_{2} \mathrm{O}$ peaks appeared around the end of acid addition. 


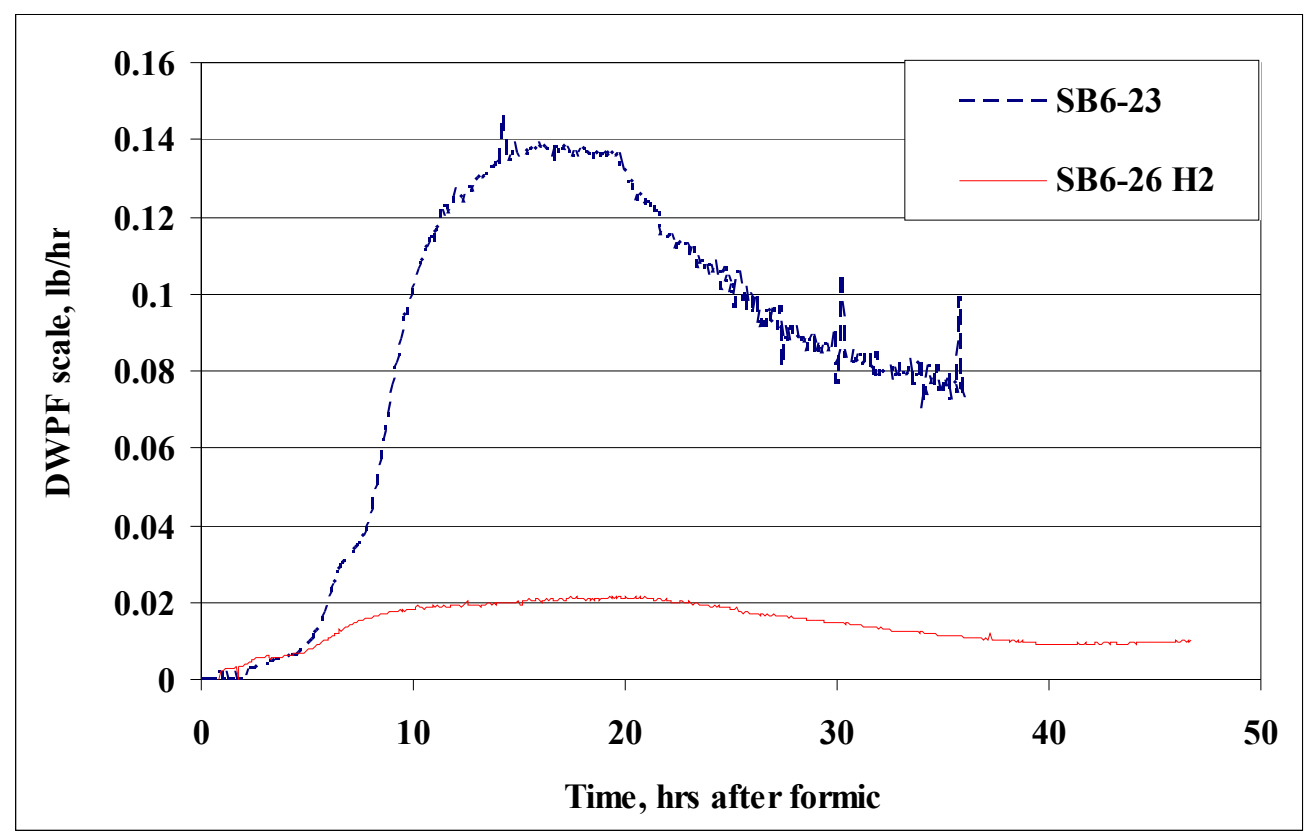

Figure 14. SB6-26 Hydrogen Generation.

Table 10. Maximum observed gas generation rates, SB6-26

\begin{tabular}{|c|c|c|c|}
\hline Gas & $\begin{array}{c}\text { SB6-23, DWPF } \\
\mathbf{l b} / \mathbf{h r}\end{array}$ & $\begin{array}{c}\text { SB6-26, DWPF } \\
\mathbf{l b} / \mathbf{h r}\end{array}$ & $\begin{array}{c}\text { SC-9, DWPF } \\
\mathbf{l b} / \mathbf{h r}\end{array}$ \\
\hline $\mathrm{H}_{2}$ & 0.14 & 0.02 & 0.55 \\
\hline $\mathrm{N}_{2} \mathrm{O}$ & 20 & 11 & 17.2 \\
\hline $\mathrm{CO}_{2}$ & 610 & 390 & 506 \\
\hline
\end{tabular}

Table 11. Total masses generated, DWPF scale, SB6-26

\begin{tabular}{|c|c|c|}
\hline Gas & SB6-23, lb & SB6-26, lb \\
\hline $\mathrm{H}_{2}$ & 3.07 & 0.68 \\
\hline $\mathrm{N}_{2} \mathrm{O}$ & 41.6 & 34.6 \\
\hline $\mathrm{CO}_{2}$ & 1381 & 1469 \\
\hline
\end{tabular}


SRNL-STI-2010-00307

Revision 0

\subsection{Conclusions and Recommendations}

Supplemental flowsheet testing was completed using the Phase III simulant composition. The goals were to determine whether higher yield stress or SRAT cycle time extension affected the SRAT chemistry and rheology. Comparisons were made to the Phase III SRAT flowsheet testing results which used the same simulant.

Because the acid stoichiometric factor of the SB6-25 sheared sludge run is bracketed by SB6-22 (high acid run) and SB6-23 (baseline), a comparison was made to both. As hypothesized, ultrasonication increased the yield stress of the SB6-25 sludge, likely because the median particle size of the sludge decreased significantly after the ultrasonication. The following quantities lie between or near those of the bracketing runs: a) amount of mercury that was not accounted for (retained inside the SRAT vessel), b) the mercury stripping efficiency, c) ammonium concentration in the slurry, d) peak and total mass of gas generation $\left(\mathrm{H}_{2}\right.$, $\mathrm{N}_{2} \mathrm{O}$, and $\mathrm{CO}_{2}$ ), e) $\mathrm{pH}$ processing profiles, and f) elemental and anion concentrations at both the beginning and the end of the boiling period. Items a) and b) imply that mercury stripping was not altogether successful. It is interesting, however, that a drop in observed $\mathrm{Hg}$ concentration in the SRAT vessel after about 20 hours of boiling, likely to be the time when some $\mathrm{Hg}$ started sticking to the vessel, coincided with the appearance of ammonium in the vessel; however, these events did not coincide in the SB6-26 run. It is possible that ultrasonication had a small but measurable mitigating effect on $\mathrm{N}_{2} \mathrm{O}$ and $\mathrm{CO}_{2}$ production. It was also found that when the system approached neutral $\mathrm{pH}$, ammonium began to be formed, which subsequently reacted to produce ammonia gas. The ammonia scrubber successfully absorbed the ammonia from the gas stream. The measured redox value $\left(\mathrm{Fe}^{2+} / \Sigma \mathrm{Fe}\right)$ is about half of the target 0.2 and there was much similarity with the Phase III flowsheet run data.

The SB6-26 extended processing run was compared to the baseline SB6-23. The SRAT product had similar rheology. The ammonium concentration in the slurry was too small to be detected, unlike SB6-23, however the slurry $\mathrm{pH}$ was above neutral for over ten hours in SB6-26 which may have caused most of the ammonia to be driven off. However, the ammonia gas and ammonium concentrations in the off-gas system were low but above the detection limits (only $11 \%$ as much ammonium was found). A significantly large fraction of mercury was retained in the SRAT vessel and the stripping of mercury was relatively poor. The $\mathrm{pH}$ profile and the elemental and anion concentrations were similar to that of the baseline. Hydrogen production, both peak and total mass, was much lower than SB6-23. The $\mathrm{N}_{2} \mathrm{O}$ and $\mathrm{CO}_{2}$ concentrations were about $50-60 \%$ of the baseline amount during acid addition. However, the total $\mathrm{N}_{2} \mathrm{O}$ generated was not much less than baseline while the extended run had a lower $\mathrm{CO}_{2}$ peak but a slightly larger total mass. The lower off-gas concentrations were expected with the lower formic acid addition rate. The redox value $\left(\mathrm{Fe}^{2+} / \Sigma \mathrm{Fe}\right)$ was about half of the target 0.2 and there was general similarity with the Phase III flowsheet study data.

Over the range studied, no evidence has been found that would indicate a major impact of yield stress on chemical behavior of SB6-G processing; however there was a small decrease observed in the total mass production of $\mathrm{N}_{2} \mathrm{O}$ and $\mathrm{CO}_{2}$. By contrast, an increase of SRAT cycle time caused modest decrease in total production of $\mathrm{N}_{2} \mathrm{O}$ and $\mathrm{CO}_{2}$, significant decrease of the generation of ammonia and hydrogen, and reduced the mercury stripping efficiency. The stripping effect is similar to that of operating under a high acid stoichiometry. Apparently the route to inhibiting the catalyst(s) generating both hydrogen (from Rh) and ammonium, perhaps involving the formation of mercury-noble metal amalgams (rendering these inert), were followed by both the high acid and extended time runs, but not the other SB6-G simulant runs. This similarity may be able to help understand the process that is causing the formation of the mercury species that is resisting steam stripping which may also be the catalyst for ammonium formation. 


\subsection{References}

1. Koopman, D.C., Sludge Batch 6/Tank 40 Simulant Chemical Process Cell Simulations, SRNL-STI-2010-00212, Aiken, SC 29808, 2010

2. $\quad$ Bricker, J.M., Sludge Batch 6 Flowsheet Studies, HLW-DWPF-TTR-2008-0043, Rev. 0, Aiken, SC 29808, 2008

3. Newell, J.D., Simulant Development for Sludge Batch 6, SRNL-STI-2010-00219, Aiken, SC 29808, 2010

4. Lambert, D.P., Sludge Batch 6 Simulant Flowsheet Studies, SRNL-RP-2008-01341, Aiken, SC 29808, 2009

5. Stone, M.E., Lab-Scale CPC Equipment Set-Up, SRNL-PSE-2006-00074, Aiken, SC 29808, 2010

6. Koopman, D.C., A Comparison of Rheology Data for Radioactive and Simulant Savannah River Site Waste, WSRC-TR-2004-00044, Aiken, SC 29808, 2004

7. Koopman, D.C., A.I. Fernandez, and B.R. Pickenheim, Preliminary Evaluations of Two Proposed Stoichiometric Acid Equations, SRNL-L3100-2009-00146, Aiken, SC 29808, 2009

8. Bannochie, C.J., J.M. Pareizs, and D.R. Click, Tank 51 SB6 Qualification SRAT Receipt Characterization, SRNL-L3100-2010-00027, Aiken, SC 29808, 2010

9. Bannochie, C.J. and J.M. Pareizs, Tank 51 SB6 Qualification SRAT Cycle Observations and Key Results, SRNL-L3100-2010-00072, Aiken, SC 29808, 2010

10. Fernandez, A.I., R\&D Directions for SB6-G Shearing Target Study, SRNL-L3100-201000038, Aiken, SC 29808, 2010

11. Irani, R.R. and C.F. Callis, Particle Size: Measurement, Interpretation, and Application. 1963, New York: John Wiley \& Sons.

12. Fernandez, A.I., Rheological and Elemental Analyses of Simulant SB5 Slurry Mix Evaporator-Melter Feed Tank Slurries, SRNL-STI-2009-00751, Aiken, SC 29808, 2010

13. Koopman, D.C. and D.R. Best, Sludge Batch 6 Phase II Flowsheet Simulations, SRNLSTI-2010-00041, 2010

14. Bandura, A.V. and S.N. Lvov, The Ionization Constant of Water over Wide Ranges of Temperature and Density, Journal of Physical and Chemical Reference Data, 35(1), 1530, 2006. 


\section{Appendix A}

Supplemental SRAT Run Data 
SRNL-STI-2010-00307

Revision 0

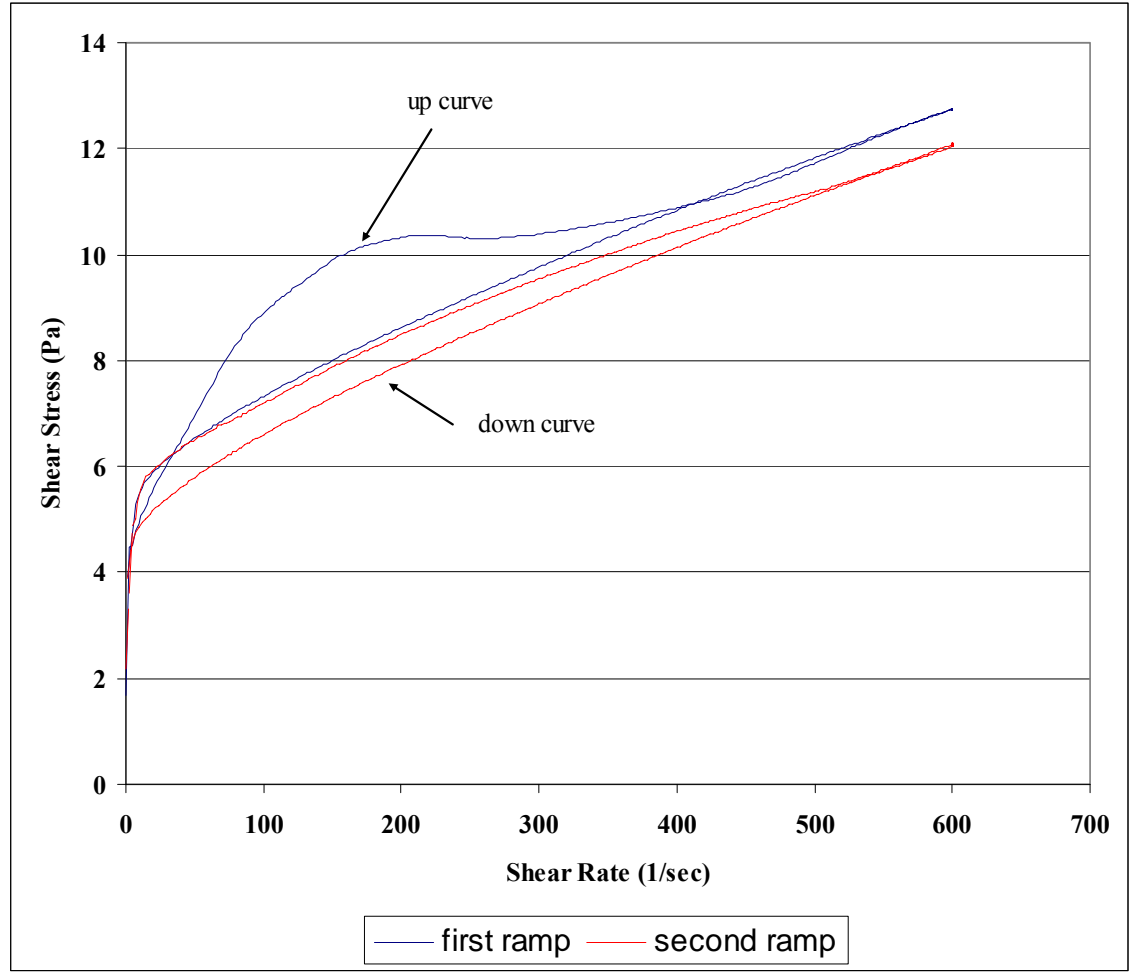

Figure 15. Rheological curve of SB6-25 using double ramp method.

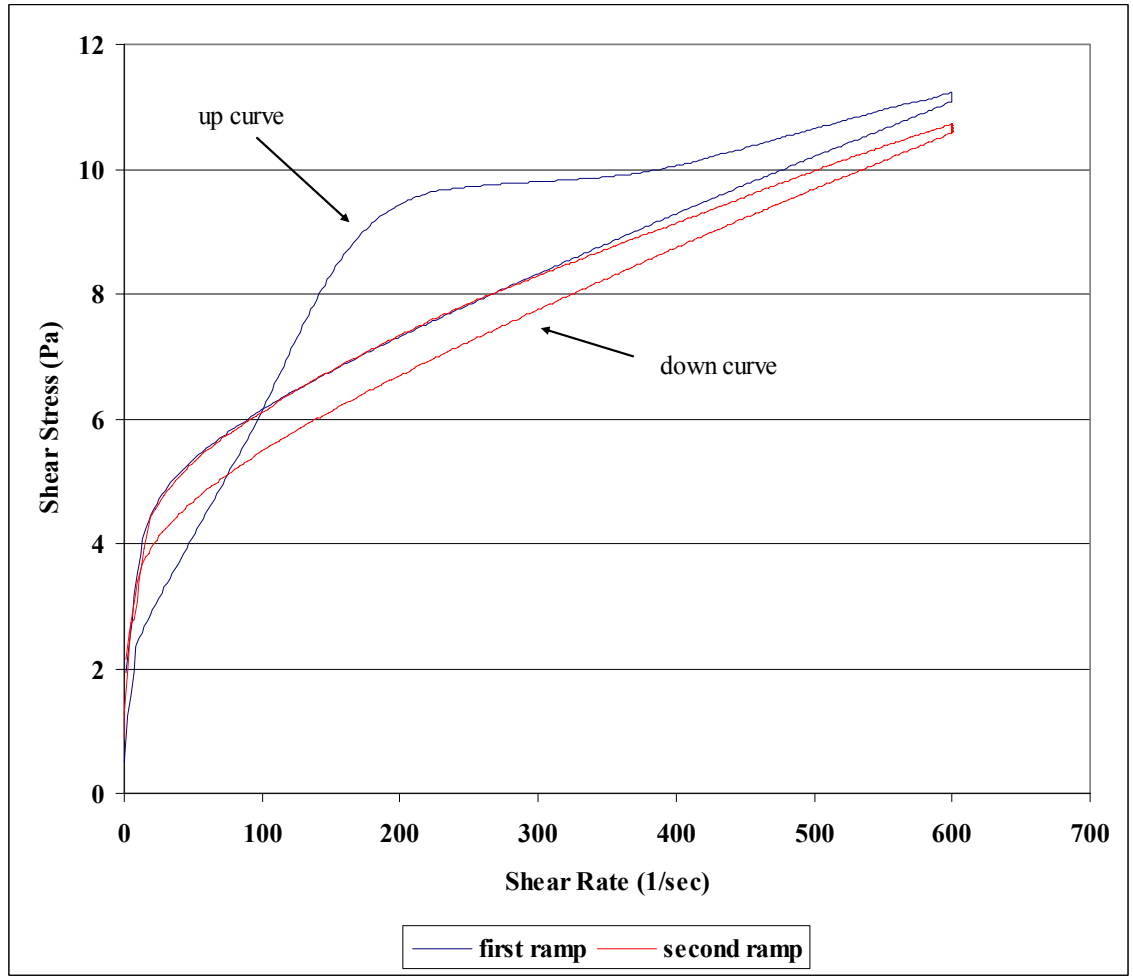

Figure 16. Rheological curve of SB6-26 using double ramp method 


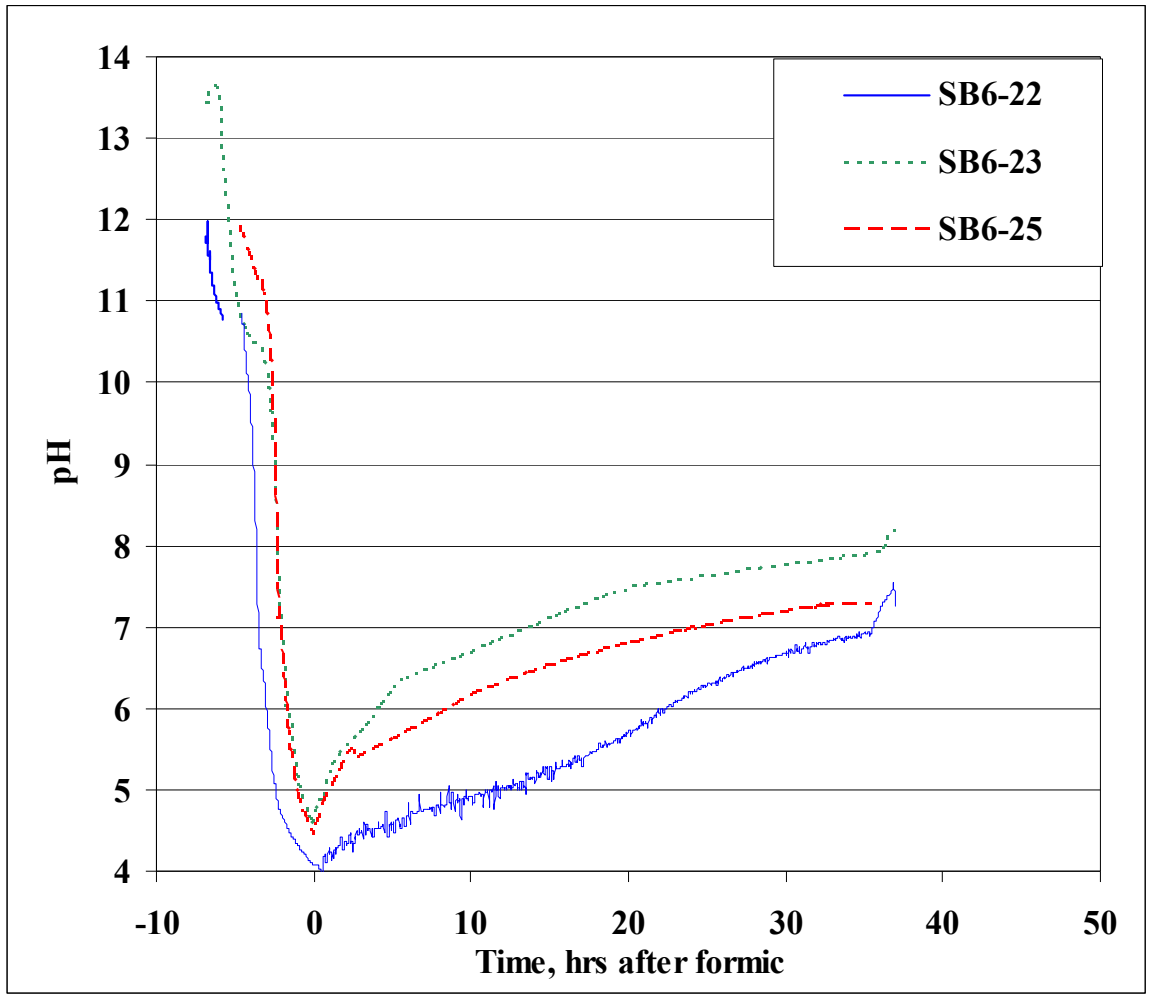

Figure 17. Comparison of pH profile of SB6-25 to SB6-22 and -23.

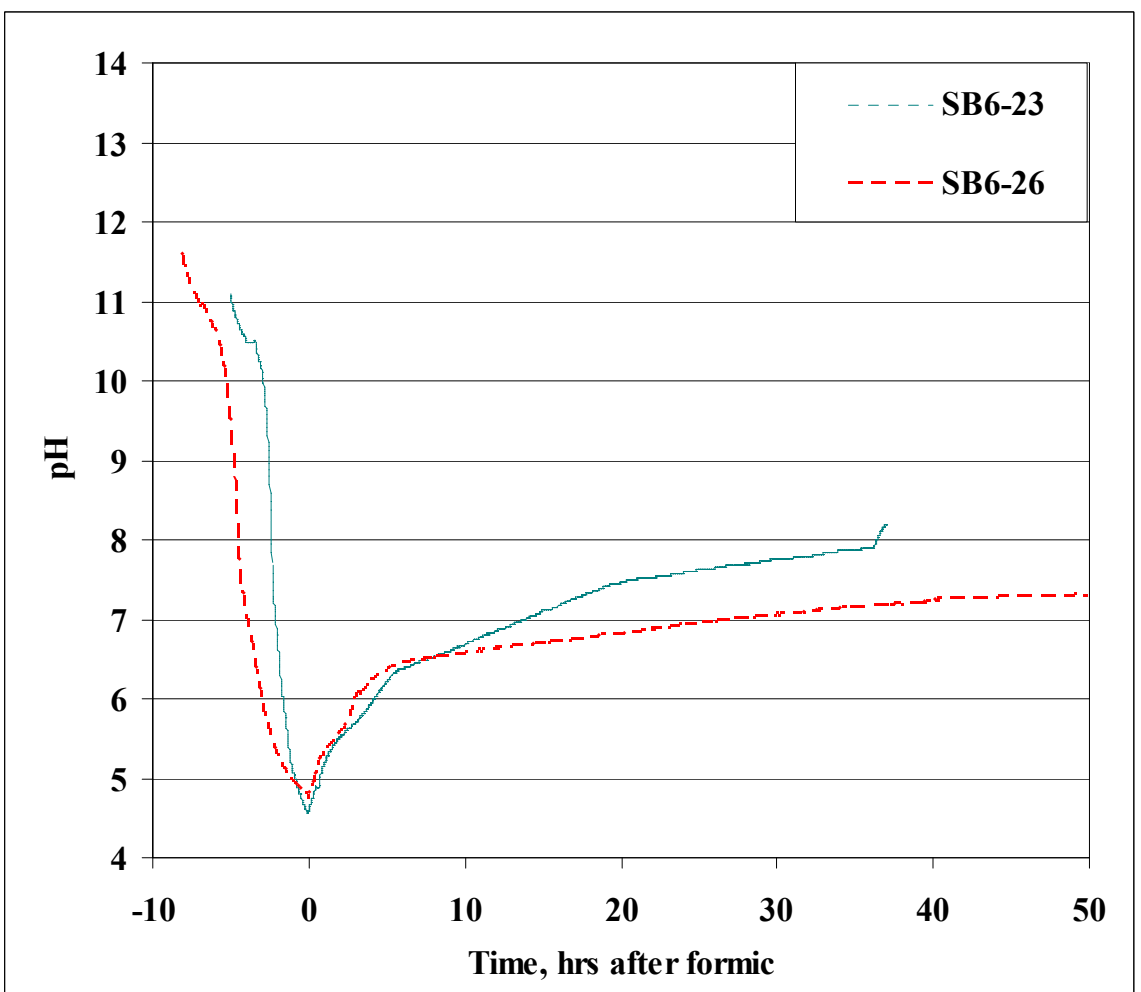

Figure 18. Comparison of pH profile of SB6-26 to SB6-23 


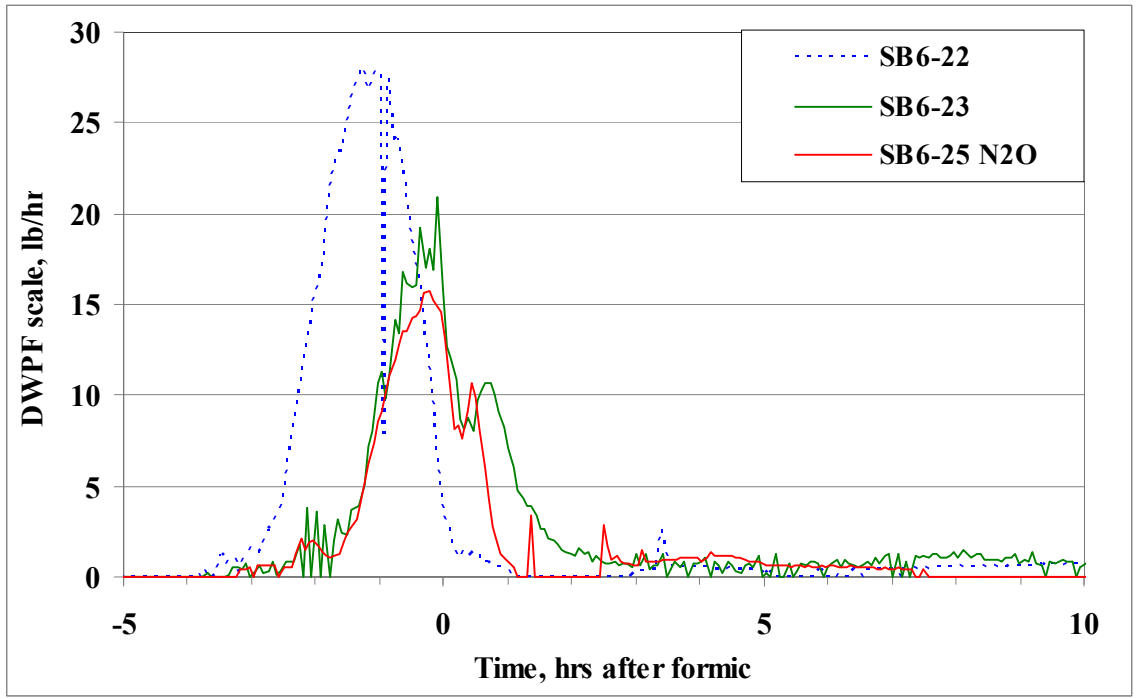

Figure 19. $\mathrm{SB6}-25 \mathrm{~N}_{2} \mathrm{O}$ generation, up to early reflux

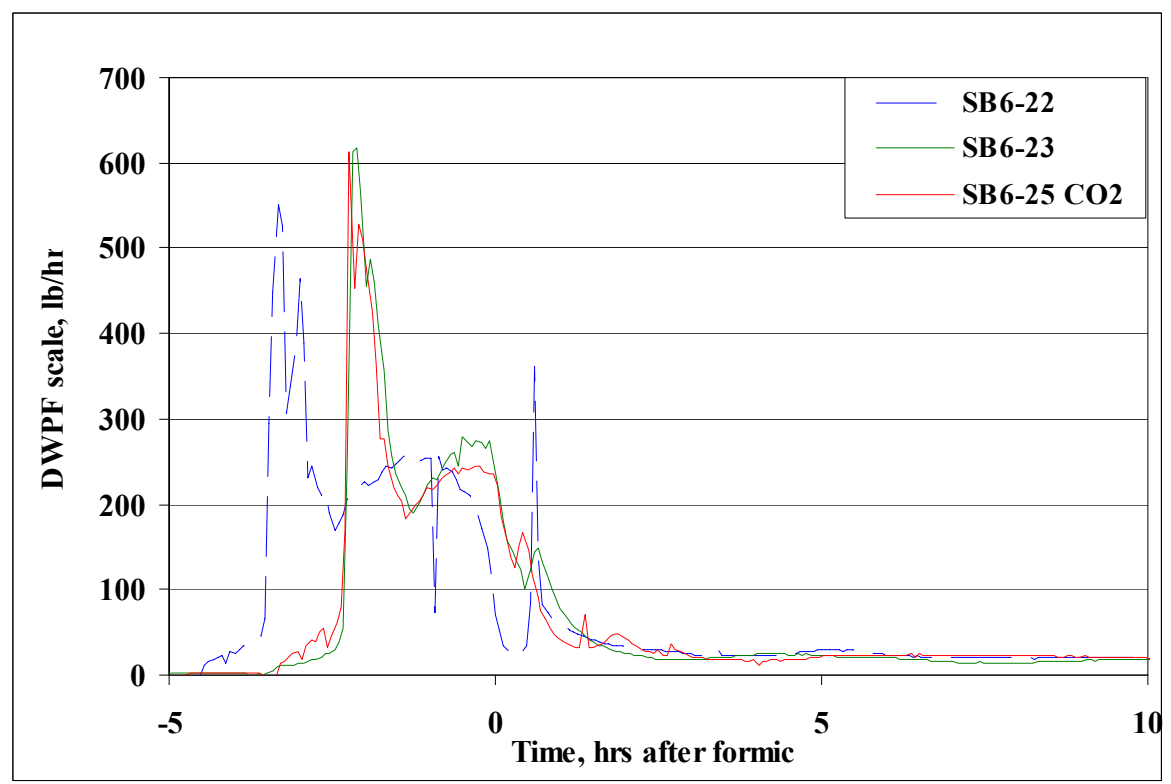

Figure 20. SB6-25 $\mathrm{CO}_{2}$ generation, up to early reflux 


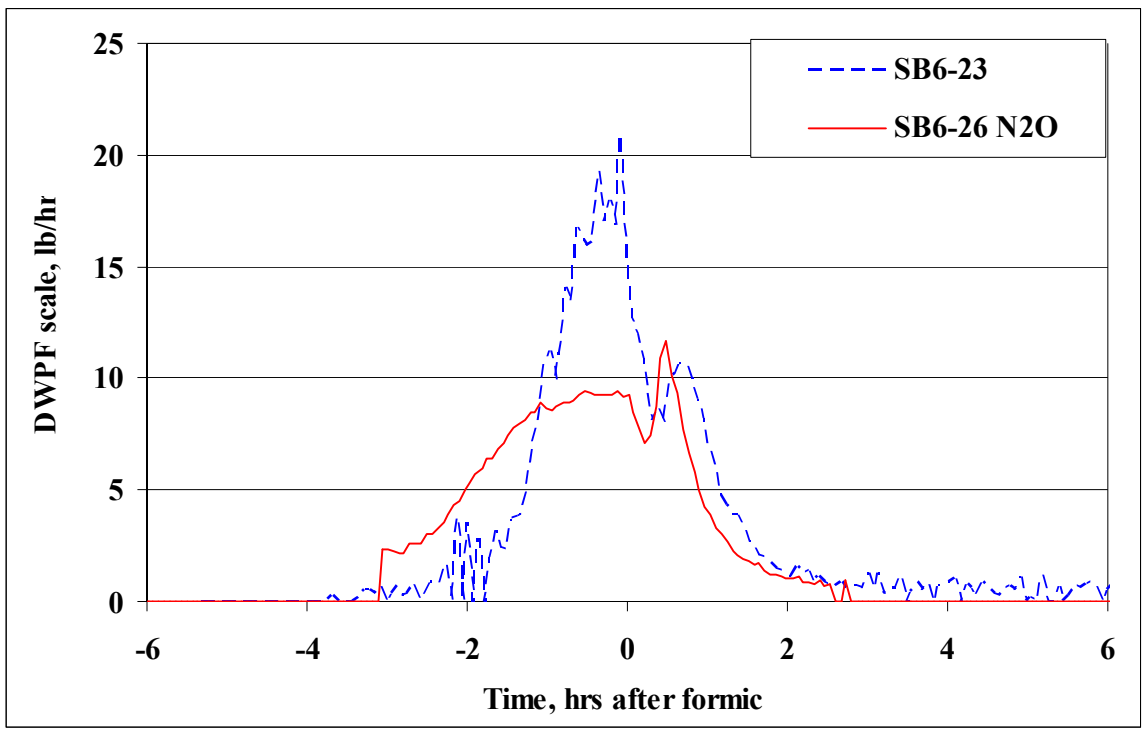

Figure 21. SB6-26 $\mathrm{N}_{2} \mathrm{O}$ generation, up to early reflux

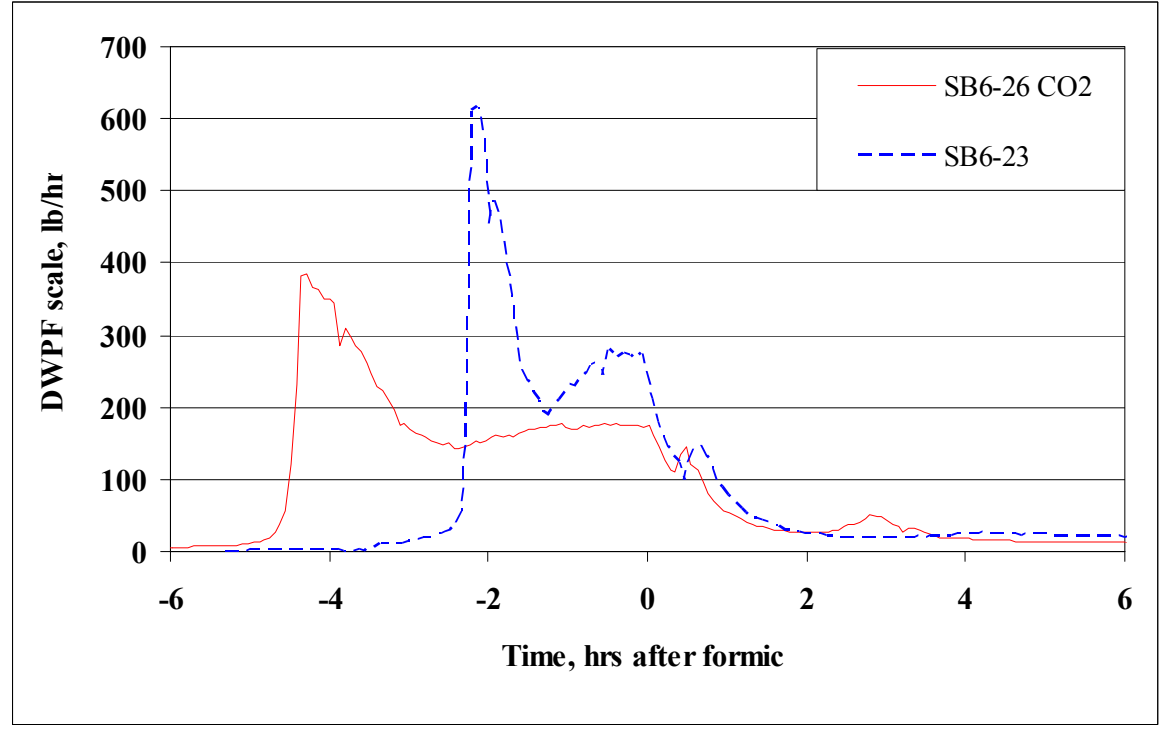

Figure 22. SB6-26 $\mathrm{CO}_{2}$ generation, up to early reflux 
Table 12. Elemental compositions of simulant and SRAT product slurries, calcined wt $\%$

\begin{tabular}{|c|c|c|c|c|c|}
\hline Element & $\begin{array}{c}\text { SB6-G } \\
\text { sludge }\end{array}$ & $\begin{array}{c}\text { SB6-25 SRAT } \\
\text { product }\end{array}$ & $\begin{array}{c}\text { SB6-26 SRAT } \\
\text { product }\end{array}$ & $\begin{array}{c}\text { SB6-22 SRAT } \\
\text { product }\end{array}$ & $\begin{array}{c}\text { SB6-23 SRAT } \\
\text { product }\end{array}$ \\
\hline $\mathrm{Al}$ & 13.0 & 13.2 & 12.9 & 13.3 & 13.0 \\
\hline $\mathrm{Ba}$ & 0.131 & 0.126 & 0.125 & 0.140 & 0.128 \\
\hline $\mathrm{Ca}$ & 0.63 & 0.603 & 0.615 & 0.587 & 0.630 \\
\hline $\mathrm{Cr}$ & 0.17 & 0.166 & 0.193 & 0.179 & 0.163 \\
\hline $\mathrm{Cu}$ & 0.095 & 0.055 & 0.060 & 0.033 & 0.099 \\
\hline $\mathrm{Fe}$ & 20.6 & 18.8 & 18.8 & 19.5 & 18.6 \\
\hline $\mathrm{K}$ & 0.08 & 0.103 & 0.090 & 0.115 & 0.083 \\
\hline $\mathrm{La}$ & 0.103 & 0.096 & 0.095 & 0.101 & 0.098 \\
\hline $\mathrm{Mg}$ & 0.50 & 0.476 & 0.473 & 0.548 & 0.505 \\
\hline $\mathrm{Mn}$ & 6.2 & 5.67 & 5.62 & 5.95 & 5.66 \\
\hline $\mathrm{Na}$ & 17.6 & 17.5 & 17.5 & 18.4 & 17.5 \\
\hline $\mathrm{Ni}$ & 2.77 & 2.57 & 2.60 & 2.72 & 2.58 \\
\hline $\mathrm{S}$ & 0.39 & 0.391 & 0.384 & 0.434 & 0.415 \\
\hline $\mathrm{Si}$ & 1.26 & 1.24 & 1.23 & 1.17 & 1.28 \\
\hline $\mathrm{Ti}$ & 0.03 & 0.028 & 0.027 & $<0.100$ & $<0.100$ \\
\hline $\mathrm{Zn}$ & 0.09 & 0.089 & 0.089 & $<0.100$ & $<0.100$ \\
\hline $\mathrm{Zr}$ & 0.26 & 0.243 & 0.243 & 0.246 & 0.275 \\
\hline
\end{tabular}

Table 13. Elemental compositions of simulant and SRAT product supernates, $\mathrm{mg} / \mathrm{L}$

\begin{tabular}{|c|c|c|c|c|c|}
\hline Element & $\begin{array}{c}\text { SB6-G } \\
\text { sludge }\end{array}$ & $\begin{array}{c}\text { SB6-25 SRAT } \\
\text { product }\end{array}$ & $\begin{array}{c}\text { SB6-26 SRAT } \\
\text { product }\end{array}$ & $\begin{array}{c}\text { SB6-22 SRAT } \\
\text { product }\end{array}$ & $\begin{array}{c}\text { SB6-23 SRAT } \\
\text { product }\end{array}$ \\
\hline $\mathrm{Al}$ & 3600 & 0.252 & 0.386 & 0.332 & 0.438 \\
\hline $\mathrm{Ba}$ & $<0.100$ & 0.411 & 0.349 & $<0.100$ & $<0.100$ \\
\hline $\mathrm{Ca}$ & 5.85 & 983 & 1010 & 1070 & 709 \\
\hline $\mathrm{Cr}$ & 52.4 & 0.049 & 0.052 & $<0.100$ & $<0.100$ \\
\hline $\mathrm{Cu}$ & $<1.00$ & $<0.010$ & $<0.010$ & $<0.100$ & $<0.100$ \\
\hline $\mathrm{Fe}$ & $<0.100$ & $<0.010$ & $<0.010$ & $<0.100$ & $<0.100$ \\
\hline $\mathrm{La}$ & $<0.100$ & $<0.010$ & $<0.010$ & 0.099 & $<0.100$ \\
\hline $\mathrm{K}$ & 280 & 391 & 358 & 621 & 485 \\
\hline $\mathrm{Mg}$ & $<0.100$ & 398 & 379 & 564 & 63.7 \\
\hline $\mathrm{Mn}$ & $<0.100$ & 2535 & 2510 & 4141 & 183 \\
\hline $\mathrm{Ni}$ & $<0.100$ & 0.053 & 0.047 & 0.201 & $<0.100$ \\
\hline $\mathrm{P}$ & $<10.0$ & 1.37 & 1.24 & 0.3793 & 0.554 \\
\hline $\mathrm{Rh}$ & 0 & 1.11 & 0.432 & 0.831 & 1.657 \\
\hline $\mathrm{Ru}$ & 0 & 1.01 & 0.638 & 5.05 & $<0.100$ \\
\hline $\mathrm{S}$ & 975 & 364 & 423 & 481 & 537 \\
\hline $\mathrm{Si}$ & 2.20 & 19.2 & 14.3 & 28.2 & 11.7 \\
\hline $\mathrm{Ti}$ & $<0.100$ & $<0.010$ & $<0.010$ & $<0.100$ & $<0.100$ \\
\hline $\mathrm{Zn}$ & $<0.100$ & $<0.010$ & $<0.010$ & $<0.100$ & $<0.100$ \\
\hline $\mathrm{Zr}$ & $<0.100$ & $<0.010$ & $<0.010$ & $<0.100$ & $<0.100$ \\
\hline
\end{tabular}


Table 14. Anion composition of SRAT slurry one-half hour from end of reflux, $\mathrm{mg} / \mathrm{kg}$ slurry

\begin{tabular}{|c|c|c|c|c|}
\hline Element & SB6-25 SRAT & SB6-26 SRAT & SB6-22 SRAT & SB6-23 SRAT \\
\hline $\mathrm{F}^{-}$ & $<100$ & $<100$ & $<100$ & $<100$ \\
\hline $\mathrm{Cl}^{-}$ & 461 & 448 & 527 & 495 \\
\hline $\mathrm{NO}_{2}^{-}$ & $<100$ & $<100$ & $<100$ & $<100$ \\
\hline $\mathrm{NO}_{3}^{-}$ & 26059 & 28262 & 27100 & 29154 \\
\hline $\mathrm{SO}_{4}^{-2}$ & 578 & 508 & 529 & 629 \\
\hline $\mathrm{HCO}_{2}^{-}$ & 48619 & 52073 & 37000 & 39326 \\
\hline $\mathrm{PO}_{4}^{-3}$ & $<100$ & $<100$ & $<100$ & $<100$ \\
\hline
\end{tabular}

Table 15. Anion composition of SRAT slurry at end of acid addition, $\mathrm{mg} / \mathrm{kg}$ slurry

\begin{tabular}{|c|c|c|c|c|}
\hline Element & SB6-25 SRAT & SB6-26 SRAT & SB6-22 SRAT & SB6-23 SRAT \\
\hline $\mathrm{F}^{-}$ & $<100$ & $<100$ & $<100$ & $<100$ \\
\hline $\mathrm{Cl}^{-}$ & $<100$ & 111 & 400 & 200 \\
\hline $\mathrm{NO}_{2}^{-}$ & 2392 & 2610 & $<400$ & 4100 \\
\hline $\mathrm{NO}_{3}^{-}$ & 20967 & 20689 & 27200 & 21900 \\
\hline $\mathrm{SO}_{4}^{-2}$ & 139 & 155 & 300 & 200 \\
\hline $\mathrm{HCO}_{2}^{-}$ & 46987 & 44755 & 61300 & 49100 \\
\hline $\mathrm{PO}_{4}^{-3}$ & $<100$ & $<100$ & $<100$ & $<100$ \\
\hline
\end{tabular}


Table 16. Elemental compositions of simulant and SRAT supernate at end of acid addition, $\mathbf{m g} / \mathrm{L}$

\begin{tabular}{|c|c|c|c|c|c|}
\hline Element & $\begin{array}{l}\text { SB6-G } \\
\text { sludge }\end{array}$ & SB6-25 SRAT & SB6-26 SRAT & SB6-22 SRAT & SB6-23 SRAT \\
\hline $\mathrm{Al}$ & 3600 & 91.3 & 19.3 & 560 & 53.2 \\
\hline $\mathrm{Ba}$ & $<0.100$ & 1.44 & 1.27 & 1.61 & 1.30 \\
\hline $\mathrm{Ca}$ & 5.85 & 902 & 987 & 1030 & 947 \\
\hline $\mathrm{Cr}$ & 52.4 & 5.49 & 1.47 & 26.1 & 2.72 \\
\hline $\mathrm{Cu}$ & $<1.00$ & 22.7 & 12.8 & 62.3 & 17.3 \\
\hline $\mathrm{Fe}$ & $<0.100$ & 11.1 & 1.97 & 149 & 4.28 \\
\hline $\mathrm{K}$ & 280 & 212 & 238 & 371 & 263 \\
\hline $\mathrm{La}$ & $<0.100$ & 7.59 & 5.03 & 13.8 & 4.96 \\
\hline $\mathrm{Mg}$ & $<0.100$ & 333 & 352 & 446 & 365 \\
\hline $\mathrm{Mn}$ & $<0.100$ & 5945 & 5285 & 8340 & 6015 \\
\hline $\mathrm{Ni}$ & $<0.100$ & 1030 & 732 & 1905 & 918 \\
\hline $\mathrm{Rh}$ & $0 \dagger$ & 22.4 & 21.5 & 2.94 & 25.0 \\
\hline $\mathrm{Ru}$ & $0 \dagger$ & 32.6 & 25.4 & 25.1 & 32.8 \\
\hline $\mathrm{S}$ & 975 & 415 & 464 & 482 & 484 \\
\hline $\mathrm{Si}$ & 2.20 & 21.6 & 19.5 & 31.7 & 18.6 \\
\hline $\mathrm{Ti}$ & $<0.100$ & $<0.010$ & $<0.010$ & $<0.100$ & $<0.100$ \\
\hline $\mathrm{Zn}$ & $<0.100$ & 0.699 & 0.690 & 25.2 & 7.045 \\
\hline $\mathrm{Zr}$ & $<0.100$ & 0.033 & $<0.010$ & 0.897 & $<0.100$ \\
\hline
\end{tabular}

$\dagger-$ note that noble metals were added to each individual run and were not in the SB6-G sludge

Table 17. Anion composition of MWWT composite dewater condensate, $\mathrm{mg} / \mathrm{kg}$

\begin{tabular}{|c|c|c|c|c|}
\hline Element & SB6-25 & SB6-26 & SB6-22 & SB6-23 \\
\hline$F^{-}$ & $<100$ & $<100$ & $<100$ & $<5$ \\
\hline $\mathrm{Cl}^{-}$ & $<100$ & $<100$ & $<100$ & $<5$ \\
\hline $\mathrm{NO}_{2}^{-}$ & $<100$ & 178 & $<100$ & 7 \\
\hline $\mathrm{NO}_{3}^{-}$ & 5895 & 4050 & 897 & 6180 \\
\hline $\mathrm{SO}_{4}^{-2}$ & $<100$ & $<100$ & $<100$ & $<5$ \\
\hline $\mathrm{HCO}_{2}^{-}$ & 1250 & 371 & $<100$ & 271 \\
\hline $\mathrm{PO}_{4}^{-3}$ & $<100$ & $<100$ & $<100$ & $<5$ \\
\hline
\end{tabular}




\section{Distribution:}
A. B. Barnes, 999-W
D. A. Crowley, 773-43A
S. D. Fink, 773-A
B. J. Giddings, 786-5A
C. C. Herman, 999-W
S. L. Marra, 773-A
F. M. Pennebaker, 773-42A
C. J. Bannochie, 773-42A
J. M. Bricker, 704-27S
T. L. Fellinger, 704-26S
J. M. Gillam, 766-H
B. A. Hamm, 766-H
E. W. Holtzscheiter, 704-15S
J. F. Iaukea, 704-30S
M. T. Keefer, 766-H
D. P. Lambert, 999-W
R. T. McNew, 704-27S
J. D. Newell, 999-W
J. E. Occhipinti, 704-S
J. M. Pareizs, 773-A
D. K. Peeler, 999-W
B. R. Pickenheim, 999-W
J. W. Ray, 704-S
S. H. Reboul, 773-A
H. B. Shah, 766-H
D. C. Sherburne, 704-S
M. E. Stone, 999-W
J. R. Zamecnik, 999-W 